\title{
LAND ENTITLEMENT UNDER TREATY 8
}

\author{
ROBERT METCS* AND CHRISTOPHER G. DEVLIN**
}

This article provides an analysis of the land entitlement provisions of Treaty 8 as they relate to current federal treaty land entitlement (TLE) policy and to the judgment in Lac La Ronge. The authors identify and analyze significant textual, contextual, and historical differences between Treaty 8 and the previous seven numbered Treaties. On the basis of that analysis, the authors advance various proposals in support of a principled policy approach to determining the existence and extent of the obligations placed upon the Crown by Treaty 8 and the land entitlement provisions contained therein.
Cet article analyse les dispositions sur les droits fonciers du Traité 8 relativement au traité fédéral actuel sur la politique sur les droits fonciers et le jugement du Lac La Ronge. Les auteurs déterminent et analysent des différences textuelles, contextuelles et historiques considérables entre le Traité 8 et les sept traités précédents. Compte tenu de cette analyse, les auteurs font plusieurs propositions visant à appuyer une démarche de politique motivée dans le but d'établir l'existence et la portée des obligations imposées à la Couronne par le Traité 8 et les dispositions sur les droits fonciers qu'il contient.

\section{TABLE OF CONTENTS}

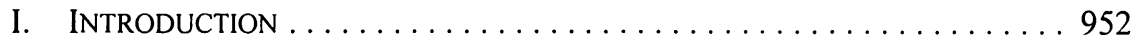

II. INTERPRETATION OF TREATY $8 \ldots \ldots \ldots \ldots \ldots \ldots \ldots \ldots \ldots \ldots \ldots$

A. THE LAND ENTITLEMENT PROVISIONS

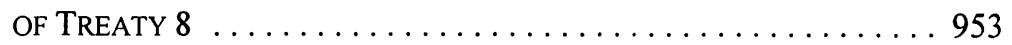

B. Legal Principles ApPlicable to the

INTERPRETATION OF TREATIES . . . . . . . . . . . . . . . 955

C. The LAC La RONGE DECISION ................... 958

D. APPLICATION OF Legal PRINCIPLES

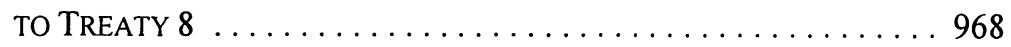

III. TREaty Land ENTItLEMENT AND Federal Policy $\ldots \ldots \ldots \ldots \ldots 91$

A. CURRENT FEDERAL POLICY ON

TREATY LAND ENTITLEMENT . . . . . . . . . . . . . . . . . 981

B. ONUS OF PROOF ......................... 987

C. QUALITY OF LAND SURVEYED FOR TREATY LAND

ENTITLEMENT PURPOSES . . . . . . . . . . . . . . . . . . 991

D. EXCLUSION OF INDIVIDUALS WITH PATERNAL

ANCESTORS WHO RECEIVED LAND OR SCRIP . . . . . . . . . . . . 993

IV. PRoposal for Policy CHANGE $\ldots \ldots \ldots \ldots \ldots \ldots \ldots \ldots \ldots$

-. $\quad$ Robert Metcs, B.A. (Toronto), M.A. (Carleton).

-. Christopher Devlin, B.A. (Victoria), LL.B. (Victoria). An Associate of the firm Woodward \& Company in Victoria, he practices in the area of Aboriginal law broadly, advising and representing First Nations on matters respecting Aboriginal rights and title, the duty of consultation, treaties and specific claims, oil and gas development, commercial transactions, leasing disputes, taxation, and on-reserve land issues. 


\section{INTRODUCTION}

Treaty 8 encompasses lands in north-eastern British Columbia, northern Alberta, northwestern Saskatchewan and southern portions of the Northwest Territories. These lands, specifically those within Alberta and British Columbia, are rich in natural resources, petroleum, and natural gas resources in particular, which provide considerable support to the economies of western Canada. It is apparent, however, that several First Nations have outstanding claims to land under Treaty 8 . These land entitlements, most of which have been unfulfilled for close to a century, are now being claimed.

All of the so-called Numbered Treaties of western Canada make provision for the survey of reserve lands. With the exception of Treaty 5 , these lands are not to exceed one square mile for each family of five or 128 acres for each individual Indian.' Treaties 8 and 10 also allow for lands in severalty at 160 acres per Indian for those who wish to live apart from Band reserves. ${ }^{2}$ On the face of things, implementation of these provisions must have appeared simple: the Indians were counted and the appropriate amount of land was surveyed. The historical record with respect to implementation of treaty land entitlements, however, indicates that the contrary in fact occurred. Several questions of interpretation have arisen. A few of them, not unrelated, are: who is eligible to be counted, when is the counting of people to begin, when is it to end or be completed, and what is to be done if not everyone was counted when the first counting occurred?

Each of these questions has had many and varied answers put to them over the years by governments, First Nations, and recently, by the courts. Canada's current interpretation of its obligations, its current policy on treaty land entitlement (TLE), is based on determining a population figure for the band as of the date reserve lands are first surveyed for them. This is referred to as date of first survey (DOFS). To this figure are added what are called late additions or certain restricted categories of eligible individuals who adhere to treaty and/or who join the band after its DOFS. Certain subtractions may also be made. The number so determined is referred to as the adjusted date of first survey (ADOFS).

In order to qualify a claim for negotiation under the federal specific claims process, the ADOFS figure for the First Nation must be greater than the total amount of reserve lands surveyed to date for that First Nation. In cases where more than one survey has been made, an outstanding treaty land entitlement will exist only when the total amount of lands surveyed for the band is less than the calculation of lands due based upon the ADOFS population figure. Current policy places the onus of proving this shortfall entirely on the First Nation.

1 Treaty 5 provides for 160 acres for each family of five, or 32 acres per person (Canada, Treaty No. 5 Between Her Majesty the Queen and the Salteaux and Swampy Cree Tribes of Indians at Beren's River and Norway House with Adhesions (28 September 1875) (Ottawa: Queen's Printer, 1969)). For copies of all of the Historic Treaties, see online: Indian and Northern Affairs Canada [INAC] <www.aincinac.gc.ca/pr/trts/hti/site/trindex_e.html>.

2 See Canada, Treaty No. 8 made June 21, 1899 and Adhesions, Reports (Ottawa: Queen's Printer, 1966), online: INAC <www.ainc-inac/gc/pr/trts/trty8_e.html>; and Canada, Treaty No. 10 and Reports of Commissioners (Ottawa: Queen's Printer, 1966), online: INAC <www.ainc-inac.gc/pr/trts/trty10 e.html>. 
The most recent legal decision to consider the issue of treaty land entitlement was Lac La Ronge Indian Band v. Canada, where the Saskatchewan Court of Appeal held that, pursuant to Treaty 6, any land entitlement should be determined according to the population of the band at date of first survey, with certain specified adjustments, even where the Crown did not survey the entire entitlement at that time. ${ }^{3}$ In so ruling, the Court rejected what has been termed the "current population formula," whereby the population is determined as of the date when the entitlement is fulfilled in its entirety. The Supreme Court of Canada did not grant leave to appeal on this decision. ${ }^{4}$

With respect to Treaty 8 , however, strong legal and historical factors suggest that the actual extent of outstanding treaty land entitlements far exceeds the obligation contemplated by current Federal policy or as determined for Treaty 6 by the Court in Lac La Ronge. Many policy restrictions set in place by Canada are quite arbitrary, bearing little relation to the text of Treaty 8 , much less to its spirit and intent.

This article provides an analysis of the land entitlement provisions of Treaty 8 as related to current federal TLE policy and to the judgment of the Saskatchewan Court of Appeal in Lac La Ronge. Significant textual, contextual, and historical differences between Treaty 8 and the previous seven Numbered Treaties are identified. These differences, it is argued, render problematic any interpretation of the former treaty that purports to ground itself on the ruling in Lac La Ronge and/or on the principles upon which are based the various elements that now comprise current federal policy. On the basis of this analysis, various proposals are advanced in support of a principled policy approach to determine the existence and extent of the obligation placed upon the Crown by Treaty 8 and the land entitlement provisions contained therein.

\section{INTERPRETATION OF TREATY 8}

\section{A. The Land Entitlement Provisions of Treaty 8}

Initial negotiations with respect to Treaty 8 were scheduled for 8 June 1899 near the present site of Grouard, Alberta, at the western edge of Lesser Slave Lake. The Treaty and Half-breed Commissioners left Athabasca Landing on June 2, but encountered delay immediately due to inclement weather and transportation difficulties. ${ }^{5}$ The party did not reach

(2001), 213 Sask. R. 1, [2001] 4 C.N.L.R. 120 [Lac La Ronge cited to C.N.L.R.].

[2001] S.C.C.A. No. 647 (QL).

The Treaty 8 Commission was comprised of David Laird (Chief Commissioner, former Minister of the Interior in the Mackenzie Administration and former Lieutenant-Governor of the North-West Territories, appointed by Laurier to the post of Indian Commissioner for the North-West Territories in 1898), James Ross (Minister of Public Works in the Territorial Government), and James A. McKenna (Private Secretary to Clifford Sifton, Minister of the Interior and Superintendent-General of Indian Affairs). Attached to the Commission in an advisory capacity was Father Albert Lacombe, OMI, a Met is Catholic priest who had lived with the prairie Indians since 1852 . He had accompanied the Treaty 7 Commission, led by Laird, in 1877. An Order-in-Council dated 3 May 1899 had recommended that Lacombe be enlisted to counter expected difficulties based on reports of unrest amongst the Indians in the proposed Treaty area. Initially hesitant (he was then 72 years of age), Lacombe accepted after being prodded by Laurier himself. His usefulness in gaining the trust of the Indians was noted by Sifton in the House of Commons: "there is no man in the northwest looked upon by the Indians with the same reverence and affection as Father Lacombe" (Canada, House of Commons Debates (1899), col. 5694, 
Lesser Slave Lake until June 19-11 days behind schedule. According to reports filed with the Edmonton Bulletin, however, Commissioner Ross had been present in the area by June 6 , assuring the assembled Indians and Metis that the Commissioners and Father Lacombe had departed and would arrive shortly. ${ }^{6}$ In the Interim, Ross explained the purpose of the Treaty and requested that the Indians elect amongst themselves a Chief and a Headman to represent them. Kinosayoo was subsequently chosen Chief, with Moostoos, Felix Giroux, Weecheewayis, and Charles Neesuetasis elected as Headmen.

Commissioner David Laird delivered his opening address on June $20 .^{7}$ There ensued various speeches by the Indians and responses by the Commissioners and Father Lacombe. The meeting for the day adjourned with general agreement and the Commissioners retired to prepare the Treaty document that was to be read to the Indians the following day. What happened next was recorded by the Edmonton Bulletin: "Commissioner Laird spoke and asked the chief and his councilmen if they were satisfied to come forward and sign. They hesitated a little, but finally came forward and touched the pen. Harrison Young, the secretary, wrote their names." ${ }^{8}$ The land entitlement provisions of the Treaty read as follows:

And Her Majesty the Queen hereby agrees and undertakes to lay aside reserves for such bands as desire reserves, the same not to exceed in all one square mile for each family of five for such number of families as may elect to reside on reserves, or in that proportion for large or smaller families; and for such families or individual Indians as may prefer to live apart from band reserves. Her Majesty undertakes to provide land in severalty to the extent of 160 acres to each Indian, the land to be conveyed with a proviso as to non-alienation without the consent of the Governor-General in Council of Canada, the selection of such reserves, and lands in severalty, to be made in the manner following, namely, the Superintendent General of Indian Affairs shall depute and send a suitable person to determine and set apart such reserves and lands, after consulting with the Indians concerned as to the locality which may be found suitable and open for selection. ${ }^{9}$

What is clear is that the individuals and families who adhered to Treaty 8 were entitled to choose between taking their land entitlement in common (those who elected "to reside on reserves") or in severalty (those who elected to "live apart from band reserves"). What is not clear is the method for determining the extent of the entitlement and the effects, if any,

quoted in Rene Fumolean, As Long as this Land Shall Last: A History of Treaty 8 and Treaty 11, 18701939 (Toronto: McLelland and Stewart, 1973) at 66).

Edmonton Bulletin (10 July 1899), Ottawa, National Archives of Canada [NAC] (RG 10, vol. 3848, file 75,236-1). The Bulletin filed six reports on the Treaty 8 and Half-breed Commissions between 6 July 1899 and 25 September 1899 .

7 The opening address and an account of subsequent events related to the negotiation and signing of the Treaty are contained in Charles Mair, Through the Mackenzie Basin: An Account of the Signing of Treaty No. 8 and the Scrip Commission, 1899, Introductions by David W. Leonard \& Brian Calliou (Edmonton: University of Alberta Press and Edmonton and District Historical Society, 1999). Mair, who served as Secretary to the Half-breed Commission, filed eight reports on the negotiations for the Globe between the dates of 15 July 1899 and 9 September 1899. These reports formed the basis for his later book and do not differ significantly in their account of the various proceedings.

$8 \quad$ Supra note 6. In his memoirs, Bishop Grouard states that "the chief and his four councillors took the pen and the treaty was signed" (Souvenirs de mes soixante ans d'apostolat dans l'AthabaskaMackenzie, Souvenirs de mes soixante ans d'apostolat dans l'Athabaska-Mackenzie (Winnipeg: la Liberte, 1922), per English translation held in the Grey Nuns Archives.)

Treaty 8 , supra note 2 . 
arising from its partial fulfilment at any one time. From this basis arise the various conflicting interpretations of the land entitlement provisions.

The discussion begins, therefore, with a review of applicable legal principles adopted by the courts with respect to the interpretation of treaties, followed by a close reading of the $L a c$ La Ronge decision. Key interpretive principles and the decision in Lac La Ronge are then examined vis-à-vis Treaty 8.

\section{B. Legal Principles Applicable to the InTERPRetation OF Treaties}

With respect to the interpretation of treaties with Aboriginal people, the general principles were conveniently set out by the British Columbia Court of Appeal in Saanichton Marina Ltd. v. Tsawout Indian Band.

In approaching the interpretations of Indian treaties the courts in Canada have developed certain principles which have been enunciated as follows:

(a) The treaty should be given a fair, large, and liberal construction in favour of the Indians;

(b) Treaties must be construed not according to the technical meaning of their words, but in the sense that they would naturally be understood by the Indians;

(c) As the honour of the Crown is always involved, no appearance of "sharp dealing" should be sanctioned;

(d) Any ambiguity in wordings should be interpreted as against the drafters and should not be interpreted to the prejudice of the Indians if another construction is reasonably possible;

(e) Evidence by conduct or otherwise as to how the parties understood the treaty is of assistance in giving it content.

The expression of these principles is to be found in Nowegijick v. R., [1983] 1 S.C.R. 29 ... Simon v. R., [1985] 2 S.C.R. 387 ... R. v. Bartleman ... R. v. Taylor (1981) ... 62 C.C.C. (2d) 227 (C.A.). ${ }^{10}$

This law was extensively reviewed by the Supreme Court of Canada in its companion decisions in R. v. Marshall." Madam Justice McLachlin (as she then was) provided a summary of the law of respecting treaty interpretation that closely followed the summary in Saanichton Marina:

1. Aboriginal treaties constitute a unique type of agreement and attract special principles of interpretation

2. Treaties should be liberally construed and ambiguities or doubtful expressions should be resolved in favour of the Aboriginal signatories ... 
3. The goal of treaty interpretation is to choose from among the various possible interpretations of common intention the one which best reconciles the interests of both parties at the time the treaty was signed ...

4. In searching for the common intention of the parties, the integrity and honour of the Crown is presumed...

5. In determining the signatories' respective understanding and intentions, the court must be sensitive to the unique cultural and linguistic differences between the parties...

6. The words of the treaty must be given the sense which they would naturally have held for the parties at the time ...

7. A technical or contractual interpretation of treaty wording should be avoided ...

8. While construing the language generously, courts cannot alter the terms of the treaty by exceeding what "is possible on the language" or realistic ...

9. Treaty rights of Aboriginal peoples must not be interpreted in a static or rigid way. They are not frozen at the date of signature. The interpreting court must update treaty rights to provide for their modern exercise. This involves determining what modern practices are reasonably incidental to the core treaty right in its modern context. ${ }^{12}$

Although McLachlin J. wrote for the minority, the majority did not contradict this summary of legal principles. Nor did the majority reject the following two-step model that McLachlin J. advanced with respect to treaty interpretation:

First, the words of the treaty clause at issue should be examined to determine their facial meaning, in so far as this can be ascertained, noting any patent ambiguities and misunderstandings that may have arisen from linguistic and cultural differences. This exercise will lead to one or more possible interpretations of the clause. As noted in Badger, supra, ... "the scope of treaty rights will be determined by their wording". The objective at this stage is to develop a preliminary, but not necessarily determinative, framework for the historical context inquiry, taking into account the need to avoid an unduly restrictive interpretation and the need to give effect to the principles of interpretation.

At the second step, the meaning or different meanings which have arisen from the wording of the treaty right. must be considered against the treaty's historical and cultural backdrop. A consideration of the historical background may suggest latent ambiguities or alternative interpretations not detected at first reading. Faced with a possible range of interpretations courts must rely on the historical context to determine which comes closest to reflecting the parties' common intention. This determination requires choosing "from among the various possible interpretations of the common intention the one which best reconciles" the parties' interests: Sioui, supra, .... Finally, if the court identifies a particular right which was intended to pass from generation to generation, the historical context may assist the court in determining the modern counterpart of that right: Simon, supra. ${ }^{13}$

In Marshall No. 1, Binnie J., writing for the majority of the Supreme Court, affirmed the principle that certain extrinsic evidence may be used as an aid to interpretation of Indian treaties: 
Firstly, even in a modern commercial context, extrinsic evidence is available to show that a written document does not include all of the terms of an agreement....

Secondly, even in the context of a treaty document that purports to contain all of the terms, this Court has made clear in recent cases that extrinsic evidence of the historical and cultural context of a treaty may be received even absent any ambiguity on the face of the treaty....

Thirdly, where a treaty was concluded verbally and afterwards written up by representatives of the Crown, it would be unconscionable for the Crown to ignore the oral terms while relying on the written terms. ${ }^{14}$

However, Binnie J. went on to provide this caution:

"Generous" rules of interpretation should not be confused with a vague sense of after-the-fact largesse. The special rules are dictated by the special difficulties of ascertaining what in fact was agreed to. The Indian parties did not, for all practical purposes, have the opportunity to create their own written record of the negotiations. Certain assumptions are therefore made about the Crown's approach to treaty making (honourable) which the Court acts upon in its approach to treaty interpretation (flexible) as to the existence of a treaty ... the completeness of any written record (the use, e.g., of context and implied terms to make honourable sense of the treaty arrangements) ... and the interpretation of treaty terms once found to exist.... The bottom line is the Court's obligation is to "choose from among the various possible interpretations of the common intention [at the time the treaty was made] the one which best reconciles" the Mi'kmaq interests and those of the British Crown. ${ }^{15}$

From the decision in Marshall No. I, there is little doubt that extrinsic evidence contemporaneous to the making of a treaty is as much a part of the treaty for purposes of interpretation as is the text itself in determining the understanding of the signatories at the time the treaty was made. ${ }^{16}$ What may remain less certain is whether the two-step approach favoured by McLachlin J. is a sufficiently "flexible" model given the views of Binnie J. and the majority. While, as noted above, the majority did not expressly reject McLachlin J.'s model, Binnie J. did not follow it either.

The approach taken by subsequent courts has been mixed. Justice Binnie's approach was applied in Pictou v. Canada. ${ }^{17}$ Other courts have cited with approval the list of interpretative

$14 \quad$ Ibid. at 172.

$15 \quad$ Ibid. at 174

16 It must be noted, however, that there is alternate authority from the Supreme Court of Canada which stands for the proposition that extrinsic evidence is not admissible where there is no ambiguity on the face of the treaty: R. v. Horse, [1988] 1 S.C.R. 187 at 201, [1988] 2 C.N.L.R. 112. However, this strict rule of treaty interpretation has been narrowed by the Supreme Court itself (and may, in fact, have been overruled) in R. v. Sioui, [1990] 1 S.C.R. 1025 at 1068, 3 C.N.L.R. 127 [Sioui cited to S.C.R.]; $R$. $v$. Badger, [1996] 1 S.C.R. 771, 2 C.N.L.R. 77 at para. 52 [Badger cited to C.N.L.R.]; and Marshall No. I, supra note 11 at para. 14. See discussion of same in Patrick J. Monahan, Constitutional Law, 2d ed. (Toronto: Irwin Law, 2002) at c. 14; and Catherine Bell \& Karen Buss, "The Promise of Marshall on the Prairies: A Framework for Analyzing Unfulfilled Treaty Promises" (2000) 63 Sask. L. Rev. 667 at 698 . With respect, the principles articulated in Marshall No. $I$ appear to represent the current state of the law regarding the admissibility of extrinsic evidence in the interpretation of Indian treaties. 
principles set out by McLachlin J., ${ }^{18}$ without, however, applying them formally - the exception being the Saskatchewan Court of Appeal in Lac La Ronge, as discussed below. The British Columbia Supreme Court appears to have taken a similar approach to that of McLachlin J. in Chingee v. British Columbia ${ }^{19}$ by examining the facial meaning of the treaty and then considering the historical and cultural evidence. But the Court in Chingee does not appear to have referenced this approach explicitly, due likely to the considerable jurisprudence prior to Marshall No. $l$, where the courts have acknowledged repeatedly that treaties were not to be interpreted according to contractual or international law standards, but in accord with the sui generis nature of agreements with Indians (see, for example, $R . v$. Sioui ${ }^{20}$ and $R$. v. Taylor and Williams). ${ }^{21}$

It is worth noting that there does not appear to be a judicial consensus as to the ultimate goal of treaty interpretation. The Federal Court of Appeal has reduced the interpretative approach set out by Binnie J. to choosing from among the various possible interpretations of the common intention at the time the treaty was made the one which best reconciles the Aboriginal interests and those of the Crown. ${ }^{22}$ The Federal Court (Trial Division), however, has suggested that Binnie J.'s approach does not focus "on accommodating economic and non-Native interests with Aboriginal rights, but on the obligations and responsibility of the Crown toward First Nations." ${ }^{23}$ As argued below, the latter perspective is certainly apparent in the Lac La Ronge decision.

\section{The LaC LA Ronge DeCISION}

\section{LAC LA RONGE AND TREATY 6}

The Saskatchewan Court of Appeal considered squarely the issue of an outstanding treaty land entitlement claim by the Lac La Ronge Indian Band under the terms of Treaty 6, to which the band had adhered in 1889. The land entitlement clause of Treaty 6 states:

And Her Majesty the Queen hereby agrees and undertakes to lay aside reserves for farming lands, due respect being had to lands at present cultivated by the said Indians, and other reserves for the benefit of the said Indians, to be administered and dealt with for them by Her Majesty's Government of the Dominion of Canada; provided, all such reserves shall not exceed in all one square mile for each family of five, or in that proportion for larger or smaller families, in manner following, this is to say: that the Chief Superintendent of Indian Affairs shall depute and send a suitable person to determine and set apart the reserves for each band, after consulting with the Indians thereof as to the locality which may be found to be the most suitable for them. ${ }^{24}$

R. v. Bernard, [2000] 3 C.N.L.R. 184 at 202, N.B.J. No. 138 (QL) (Prov. Ct.); and R. v. Marshall (2003), 218 N.S.R. (2d) 78, [2004] I C.N.L.R. 211 (C.A.) at para. 326

(2002), 8 B.C.L.R. (4th) 149, [2003] I C.N.L.R. 24 (B.C.S.C.) at paras. 65-77.

Supra note 16 at $139-41$.

(1981), 34 O.R. (2d) 360, [1981] 3 C.N.L.R. 114 (C.A.).

Pictou, supra note 17 at paras. 6 and 23 .

Mikisew Cree First Nation v. Canada (Minister of Canadian Heritage) (2001), 214 F.T.R. 48, [2002]

I C.N.L.R. 169 (F.C.T.D.) at 200.

2

Canada, Copy of Treaty 6 Between Her Majesty the Queen and the Plain and Wood Cree Indians and Other Tribes of Indians at Fort Carlton, Fort Pitt and Battle River with Adhesions (23 and 28 August 1876) (Ottawa: Queen's Printer, 1964), online: INAC <www.ainc.gc.ca/pr/trts/trty6/trty6_e.html>. 
Treaty 6 also provided for a census of the signatories to the treaty:

And further, that Her Majesty's Commissioners shall, as soon as possible after the execution of this treaty, cause to be taken an accurate census of all the Indians inhabiting the tract above described, distributing them in families, and shall, in every year ensuing the date hereof, at some period in each year, to be duly notified to the Indians, and at a place or places to be appointed for that purpose within the territory ceded, pay to each Indian person the sum of $\$ 5$ per head yearly. ${ }^{25}$

Mr. Justice Vancise wrote the decision for a unanimous panel of the Court. He summarized the essence of the land entitlement clause of Treaty 6 as a relatively straightforward exchange of interests between the signatories:

In return for ceding territory to Canada, the Indians received what had by then become standard in the numbered treaties: an agreement to set aside a reserve of 640 acres per family of five (128 acres per Indian)....

Treaty 6 provided for the creation of reserves but the exact location and size of the reserves were not specified. $^{26}$

It is important to note that the Treaty 6 negotiations were placed by the Court within the wider historical scope of treaty-making in Canada. This perspective is apparent throughout the decision and, as argued below, may have been determinative of the final interpretive result.

\section{INTERPRETATION OF MARSHALL NO. I IN LAC LA RONGE}

Justice Vancise considered the effect of the Marshall decisions on the interpretation of treaties. He adopted the two-step interpretative model advanced by McLachlin J. in the minority decision, finding that "although she was in dissent in the result, the approach used permits a consideration of all the principles of interpretation of treaties employed by the majority. ${ }^{27} \mathrm{He}$ summarized the two-step approach as follows:

The first step involves an examination of the words of the treaty "to determine their facial meaning in so far as this can be ascertained, noting any patent ambiguities and misunderstandings that may have arisen from linguistic and cultural differences." The second step involved considering the facial meaning having regard for the historical and cultural backdrop against which the treaties were negotiated. ${ }^{28}$

This is a simplified version of the steps set out by McLachlin J. in Marshall No. $I$. Importantly, Vancise J. omits a crucial element of the second step: "A consideration of the historical background may suggest latent ambiguities or alternative interpretations not detected at first reading." ${ }^{29}$ As discussed below, this omission may have resulted in an overly rigid application of the two-step model.

Lac La Ronge, supra note 3 at para. 17

Ibid. at n. 33.

Ibid. at para. 53.

Marshall No. I, supra note 11 at para. 83. 


\section{APPLICATION OF "STEP ONE" IN $L A C L A$ RONGE}

The "facial meaning" of the land entitlement provisions of Treaty 6 was considered by Vancise J. as follows:

The reserve land provision read in the context of the document as a whole provides some guidance. When a Band receives its entire allocation, the time for the calculation of the treaty land entitlement is the date of the survey subject to certain adjustments. Those include adjustments for living members who were not members at the time of survey, but who later joined the Band and for whom no land had been allocated. The overriding principle is that each living Indian will be counted once for the purpose of the land entitlement.

The "suitable person" sent out to determine and set apart the reserve land, after consultation as to where the reserve is to be located, must calculate the size of the reserve based on the population of the Band at or near the time the land is surveyed and set apart.

The defining or triggering mechanism for determining the size of the treaty land entitlement is the "deputing" of a suitable person to "lay aside" the reserve. Without that action, no reserve is created. The size of the reserve, by necessity (by virtue of the terms of the Treaty) is based upon the number of Indians who are members of the band at that time. In the absence of this information, the size of the land entitlement could not be ascertained given the formula to be applied in order to determine the size of the land entitlement.

The treaty does not speak directly as to when the Chief Superintendent shall depute and send a suitable person, or when and how the number of Indians shall be determined for this purpose. However, the intention, when read in the context of the whole agreement, including the provision for a census and the negotiations between the parties, is that the entitlement would be calculated on the basis of the population of the Band at or near the time the land is surveyed. This interpretation is reinforced by the reference in Treaty 6 to the taking of "the accurate census of the Indians inhabiting the tract." The census in the area covered by the treaty was to be taken "as soon as possible after the execution of the treaty." The purpose of the survey was to determine to whom an annuity of $\$ 5$ per Indian was owed. The census and pay lists were also used ... as the basis for calculating the land entitlement.

Based on this facial interpretation, it is not reasonable to contend that the date to determine the reserve should be based on the population of the Band at or on some unknown future date. The date for calculation of the reserve land entitlement occurs when the land is surveyed and set aside. That is subject only to certain adjustments to permit a bona fide determination of population entitled to treat. These additions would result in an increase in the size of the treaty reserve entitlement. Such a flexible approach permits a bona fide determination of a band's population by making provision for later adherents to be counted and included in the determination of the size of the reserve. If a Band's population was fixed at first survey one year after the date of the negotiation and execution of the treaty and a reserve set apart on that basis, the entitlement could be increased if late adherents to the treaty elected to treat and become members of a Band. This indeed did happen with the Lac La Ronge Band.

Thus, the language of the Treaty while not specific, is sufficiently clear to find that the obligation of the Crown to set aside reserve lands is crystallized at the date of first survey, subject to bona fide adjustments for late adherents. The Band concedes that this is a proper interpretation of the treaty land entitlement where the entire entitlement is allocated at the time of first survey. It does not agree, however, that this interpretation applied when Canada fails to allot the total entitlement at one time resulting in a multiple survey. I disagree 
with that submission. There is no credible basis for using a different time for calculating reserve land entitlement where a band does not receive its full entitlement. Nothing in the Treaty suggests that a different approach is to be used to determine entitlement if, for whatever reason, the whole amount of the entitlement is not set apart. The entitlement is fixed or crystallizes at the time of first survey or census as adjusted. The failure to allot the entire land may result in a claim for damages, but it does not change the date for the calculation of treaty entitlement. ${ }^{30}$

In summary, Vancise J. interpreted Treaty 6 to mean that each living Indian was to be counted once for purposes of land entitlement and that land entitlement was to be calculated on the basis of band population at or near the time lands are first surveyed. The size of the reserve was to be based upon the number of Indians who are band members "at the time of first survey or census as adjusted." ${ }^{31} \mathrm{He}$ found further that there is no credible basis in the Treaty for using a different time to calculate reserve land entitlement where a band does not receive its full entitlement at the initial survey.

It may be observed that Vancise J. made a number of striking assumptions in his analysis respecting the "facial meaning" of the land entitlement provision of Treaty 6.

First, he assumed that the census provision expressly dovetails into the land entitlement provision. On its face, the census provision is clearly for the purpose of identifying and locating all the Indians entitled to their annual payment under the Treaty. There is no explicit reference to link the census to the land entitlement. Of course, it makes some sense that once the government knew how many Indians there were, it would also then know the general extent of the land entitlement under the Treaty. But this is not "facially" apparent from the words of the Treaty itself; it is a conclusion based on an assessment of the text in its historical context.

Second, Vancise J. arbitrarily selected the crystallizing event for purposes of land entitlement to be the deputing of the surveyor and assumed that the population of the band becomes fixed in time at the moment of the deputing. Other dates that make equal sense include the date of the treaty itself (or the adhesion date as the case may be), the date the surveyor consults with the Indians, the date the lands are actually surveyed, the date of the first census or annuity paylist, or even the date that the government sets aside the reserve lands. All of these dates are reasonable on the face of the treaty, yet Vancise J. did not acknowledge this ambiguity.

Third, Vancise J. read into the language of the treaty that bona fide adjustments can be made to the population of the band for late adherents, that is, for Indians who were alive at the time the land entitlement "crystallized," but who adhered to the treaty or joined the band at a later date. Nowhere on the face of the Treaty is there a reference to late adherents. This is an assumption imported into the facial meaning of the treaty, albeit to the benefit of the Indians. 
Fourth, Vancise J. assumed that "the overriding principle" is "that each living Indian will be counted once for the purpose of the land entitlement." ${ }^{32}$ Nowhere in the text of the Treaty is this principle so expressed. Where the government failed to allot the full entitlement to land at first survey, Vancise J. was adamant that future population increases could not be accounted for in subsequent surveys. Only certain late additions could increase the land entitlement. On a purely facial reading of the treaty, however, it is entirely reasonable to assume that the Indians intended their natural increase to be counted for land entitlement purposes until such time as their entitlement was satisfied in full and that any natural increase over the period during which they waited for Canada to fulfil its part of the bargain would be entitled to their respective share of land as specified in the treaty, namely, 128 acres per person. ${ }^{33}$ There is, indeed, even less reason to assume that the Indians would have agreed to leave Canada total discretion without penalty as to when it could fulfil an entitlement fixed irrevocably at first survey. The allocation of risk for non-performance is an elementary aspect of all bargains. ${ }^{34}$ As interpreted by Vancise J., the risk attached to non-performance of the land entitlement provisions of Treaty 6 falls entirely upon the Indians, without any compensating factors apparent in the text. Under these circumstances, the consent of the Indians to these provisions should not be assumed on a reading of the text alone. If we recall that "the integrity and honour of the Crown is presumed" 35 when interpreting treaties and that "[t]reaties should be liberally construed and ambiguities or doubtful expressions should be resolved in favour of the aboriginal signatories," ${ }^{36}$ it is submitted, with respect, that any purely textual interpretation of a treaty provision that allocates the risk of non-performance by the Crown entirely onto the shoulders of Aboriginal signatories should be avoided.

Fifth, it would appear that the Court conflated the two entirely separate questions at issue: the question as to when, if at all, the entitlement is to be fixed; and the question as to what happens if the entire amount of land, if fixed at date of first survey, is not allotted at first survey. This last question is, of course, precisely the point at issue in the case. As a matter of logic, the answer to the first question does not necessarily determine the answer to the second. Nevertheless, the entire analysis of Vancise J. with respect to this latter question is contained in the following statements "There is no credible basis for using a different time for calculating reserve land entitlement where a band does not receive its full entitlement. Nothing in the Treaty suggests that a different approach is to be used to determine entitlement if, for whatever reason, the whole amount of the entitlement is not set apart." 37 And later: "If the date of first survey, as adjusted, is the correct formula for determining the extent of the reserve land owed where there was a single survey, there is no logical reason why it would not be used where there were multiple surveys." 38 With the exception of these sentences, the judgment focused entirely on determining the common intention of the parties with respect

Ibid. at para. 57 [emphasis added].

Certainly Vancise J.'s "facial" approach would allow for the accounting of the natural increase between the time the band adhered to Treaty 6 (1889) and the time of the first survey (1897), yet this was not the case. Indian Affairs based the 1897 survey on the population as it had existed in 1889 (see Lac La Ronge, ibid. at para. 120-26). See Hadley v. Baxendale (1854), 156 E.R. 145 at 151,9 Exch. 341; and Keneric Tractor Sales Ltd. v. Langille, [1987] 2 S.C.R. 440 at para. 29, (1987), 43 D.L.R. (4th) 171

Marshall No. I, supra note 11 at para. 78.

Ibid.

Lac La Ronge, supra note 3 at para. 62.

Ibid. at para. 155. 
to when the entitlement is fixed. No further consideration is given as to whether the parties had any intentions, let alone a common intention, on the question of what happens if not enough land is surveyed at first survey to meet any entitlement determined at that time. This would, perhaps, be permissible if the one intention follows necessarily from the other. But it does not. The questions are entirely separate and it is possible that the parties could have had separate intentions on the matter. Both the Crown and the bands could have intended that the entitlement be fixed at first survey and intended also that, if insufficient lands were actually surveyed at that time, additional lands were to be surveyed subsequently at current population. The intention of the parties with respect to this issue was not determined because the question was never asked. As stated by Vancise J. at the beginning of his reasons:

The principal issue raised on the appeals by Canada and Saskatchewan is whether at the time Treaty No. 6 was negotiated, the parties intended to calculate the treaty land entitlement on the basis of the population of the Band at the time the land was first set apart, with certain adjustments, or when the treaty land entitlement was not fully allotted or set apart, on the basis of the present or current population of the Band. ${ }^{39}$

Justice Vancise presented these as mutually exclusive positions, but they are not. The problem, as posed, excludes the entirely possible answer that the parties intended to employ both approaches. One question relates to what Canada was expected to do. The other question relates to what happens if Canada does not do what it was expected to do. The problem being posed in this manner, Vancise $\mathrm{J}$, in effect, took the position that the band was interested in when the entitlement was fixed, but had no interest in the time taken by Canada to fulfil it, in circumstances where settlers would be advancing rapidly to claim the choicest lands. ${ }^{40}$ This is not reasonable under any circumstances and even less so for those Vancise $\mathrm{J}$. characterized as tough negotiators.

The Court of Appeal, in effect, rectified the reserve land provision of Treaty 6 when they should have implied a term to it or ruled that the evidence did not allow for a conclusive determination of the matter. Rectification of contracts requires direct and conclusive evidence of prior agreement between the parties. This should also be the case for Indian Treaties. Where there is insufficient evidence to answer the question, "what did the parties intend?" (the basis for rectification), the court should ask the question, "what would they have intended had they turned their minds to the matter?" (the basis for implication).

An excellent summary of the difference between rectification and implication was provided by Mason J. of the High Court of Australia in Codelfa Construction Pty. Ltd. $v$. State Rail Authority of N.S.W.:

The implication of a term is to be compared, and at the same time contrasted, with rectification of the contract. In each case the problem is caused by a deficiency in the expression of the consensual agreement. A term which should have been included has been omitted. The difference is that with rectification the term which

3) Ibid. at para. 7 .

40 Justice Vancise appears to make this position explicit when he states (ibid. at para. 155) that it makes no difference whether all of the land was allocated at the date of first survey as adjusted or at some future time. What is important is that the Crown's obligation was crystallized at the date of first survey, as adjusted. It was at this time that the Band was owed a specific amount of reserve land which the Crown was obligated to provide. 
has been omitted and should have been included was actually agreed upon; with implication the term is one which it is presumed that the parties would have agreed upon had they turned their minds to it - it is not a term that they have actually agreed upon. Thus, in the case of the implied term the deficiency in the expression of the consensual agreement is caused by the failure of the parties to direct their minds to a particular eventuality and to make explicit provision for it. Rectification ensures that the contract gives effect to the parties' actual intention; the implication of a term is designed to give effect to the parties presumed intention. ${ }^{41}$

Glanville Williams describes the legal doctrine of implied terms as follows:

Judges are accustomed to read into documents and transactions many terms that are not logically implied in them. As an academic matter non-logical implication may be classified into three kinds: (i) of terms that the parties (the plural shall throughout include the singular) probably had in mind but did not trouble to express; (ii) of terms that the parties, whether or not they actually had them in mind, would probably have expressed if the question had been brought to their attention; and (iii) of terms that the parties, whether or not they had them in mind or would have expressed them if they had foreseen the difficulty, are implied by the Court because the of the Court's view of fairness or policy in consequence of rules of law. Of these three kinds of non-logical implication (i) is an effort to arrive at actual intention; (ii) is an effort to arrive at hypothetical or conditional intention - the intention that the parties would have had if they had foreseen the difficulty; (iii) is not concerned with the intention of the parties except to the extent that the term implied by the Court may be excluded by an expression of positive intention to the contrary. ${ }^{42}$

Justice Vancise found that the common intention of the parties to Treaty 6 was that treaty land entitlement be fixed at first survey. But this does not necessarily answer the question as to the intention of the parties if the entire entitlement was not fulfilled at first survey. It may have been the same or it may not have been. This is a question of fact. On this, however, the Court said nothing, save that "there is no credible basis for using a different time for calculating reserve land entitlement where a band does not receive its full entitlement. ${ }^{\prime 43} \mathrm{This}$ is not nearly enough to meet the standard for rectification, unless this standard is to be relaxed for Indian treaties. Rectification requires direct and conclusive evidence of prior agreement between the parties. But if the evidence indicates that the parties did not consider what is to happen in the event of insufficient lands being surveyed at first survey (as supported by the silence of the Treaty on the point), how could they have had a prior agreement or a common intention on the matter? If they had no prior agreement or common intention on the matter, how can the Treaty have failed to reflect it?

The proper problem in this case was not the actual intention of the parties (because there is no evidence that they ever considered the matter), but their presumed intention with respect to a failure to survey sufficient lands at the first survey to fulfill an entitlement fixed at that time. The question is one of implication as opposed to rectification. Justice Vancise, however, in accord with the legal principles he set out and because there is no evident prior agreement, proceeded to imply a common intention from the evidence and then, on the basis of this implication, proceeded to rectify the Reserve lands provision in accord with this implication. But what the Court found the parties to have agreed upon does not necessarily 
imply what they would have agreed upon if they had turned their minds to the question at issue.

The legal principles by which the Court interprets Indian treaties should recognize that it might not be possible to determine with any accuracy either the actual or presumed intentions of the parties to a treaty. Courts should not be forced to invent a common intention where none may have existed, or where the available evidence is inconclusive. Where the question of intention cannot be answered on the strict standards required, the ambiguity principle that uncertainties, ambiguities, or doubtful expressions should be resolved in favour of the Aboriginal signatories - ought to be applied.

In the result, with respect to step one of his analysis, it would appear that Vancise J. did not consider the different ambiguities or uncertainties apparent on the face of the Treaty, nor did he observe the various reasonable interpretations that may be made on the basis of the text. Instead, he justified only one and imported several inexplicable assumptions that cannot be derived directly from the text and, in the end, contorted the "facial" language of the Treaty accordingly. Indeed, it would appear that he also did not recognize or base his analysis on the proper point or problem at issue in the case. This approach appears to have perverted the methodology advanced by McLachlin J. in Marshall No. $l$ and makes the application of her second step even more problematic.

\section{APPLiCATION OF "STEP TWO" IN LAC LA RONGE}

Justice Vancise divided this step into several smaller ones: consideration of the history of treaty-making in Ontario and the West; consideration of the past conduct of the parties; and the actual history of reserve allocation to the Lac La Ronge Indian Band.

With respect to the general historical context, Vancise J. reviewed the history of treatymaking in Canada so as to assess its consistency with his facial interpretation of Treaty 6 . His review touched almost exclusively upon the Robinson Treaties and the Numbered Treaties 1 to 7 . He observed that none had specific provisions for increasing reserve size as band populations increased. ${ }^{44} \mathrm{He}$ noted the provisions in Treaties 1 and 2 for taking a "census of all Indians inhabiting the district." ${ }^{, 45}$ He made special note of a letter from Alexander Morris dated 14 October 1873 , in which Morris provided the rationale for setting aside reserves after treaty:

I have further to add, that it was found impossible, owing to the extent of the country treated for, and the want of knowledge of the circumstances of each band, to define the reserves to be granted to the Indians. It was therefore agreed that the reserves should be hereafter selected by officers of the Government, who should confer with the several bands, and pay due respect to the lands actually cultivated. ${ }^{46}$

Although Treaties 3, 4, 5, and 7 do not contain census provisions, Vancise J. concluded that: 
In the first seven treaties a uniform approach was taken with respect to the treaty process. Each subsequent treaty built on what had been negotiated in previous treaties. Each treaty was negotiated within the context of what had preceded it and in many cases many of the negotiations for the Government of Canada were involved in the negotiation of most of the treaties. ${ }^{47}$

All of the numbered treaties followed the main features of the Robinson Treaties: annuities; reserves; and, the right to fish and hunt on the unceded territory of the Crown. Most importantly, none of the treaties contain a provision for granting lands on the basis of an increase in population, not the Robinson Treaties or any of the numbered treaties. ${ }^{48}$

It must be noted that Vancise J. glossed over the "land in severalty" provisions of Treaties 8 and 10 in this sweeping generalization by conveniently not mentioning them - a point to be noted when considering the applicability of his general interpretation of treaty land entitlement to these treaties. Also, that the Robinson Treaties and Treaties 1-7 did not provide explicitly for an increase in population can say nothing to the common intention of the parties if the prevailing perception was that the entire entitlement for each band would be fulfilled on the initial attempt. In the absence of evidence that the possibility of multiple surveys arising from errors in calculation at DOFS had been considered, the lack of any explicit reference in the Treaty "for granting lands on the basis of an increase in population"49 may just as plausibly indicate that the issue or possibility had not been considered by the parties at all. Nevertheless, Vancise J. went on to conclude that

there was a common intention that the reserve land entitlement would be determined, allocated and set apart within a reasonable period of time. This is consistent with the policy of Canada to open up the lands for settlement and with the Indians' desire to treat with Canada to permit them to make the transition to agriculture. ${ }^{50}$

This is the first acknowledgement by Vancise J. of what is evident on the face of Treaty 6 - that the particular Indians of that treaty (and also, perhaps, of the Robinson Treaties and Treaties 1-5) were either cultivating the land or were destined to do so by way of government policy. What is also striking is how this part of the judgment appears focused on the general intention of Canada with respect to treaty-making; it is only in the final, concluding paragraph that Vancise J. made reference to this wish of the Indians to pursue agriculture. The overarching historical context described by Vancise J. is clearly that of Canada's intentions, not those of its first peoples.

With respect to the subsequent conduct of the parties, Vancise J. found no consistent course of conduct from which one could deduce the intention of the parties as to the calculation date for land entitlement. ${ }^{51} \mathrm{He}$ concluded, however, as follows: "Notwithstanding, the lack of a uniform policy on treaty location and selection, the field surveyors adopted the general practice of determining the land entitlement by counting the members of the band at the time of the survey. This was usually done by counting the number of members on the 
most recent treaty annuity pay list." ${ }^{, 52}$ More importantly, Vancise J. specifically considered the historical fact of multiple surveys:

Twenty-three reserves [in Saskatchewan] were involved in a multi-survey land entitlement, and did not receive all the reserve land entitlement at the time of first survey. Of those, only three bands, Cowesses, Thunderchild and Yellowquill are relied on by the Band as examples of the application of the current population formula. Two of those Bands, Cowesses and Thunderchild, were in a state of formation at the time they originally received reserve land and cannot be considered as truly multiple surveys because the populations changed. ${ }^{53}$

The most germane of the three examples was the Yellow Quill Band. This was a band that adhered to Treaty 6 in 1876, was divided into three separate groups, was paid using three separate paylists from 1876 to 1906, and was formally split into three separate bands in 1907 . The first survey in 1881 resulted in land allocation for two of the subgroups that fell short of the population of these two subgroups at date of first survey. In 1889, the third subgroup was allocated 15 square miles, rather than be forced to relocate to either of the existing reserves. The additional land allocated exceeded the land entitlement for the population of this third subgroup, as the government expected the band to grow through late adhesions. Justice Vancise concluded that for this particular band "considerations other than the current population of the band entered into the calculations of reserve entitlement and the ultimate allotment." 54 It should be noted that this statement does not reject what is apparent on the historical record: that the current population of the Yellow Quill Band entered into the calculation of the band's entitlement. Indeed, the historical record would appear to indicate quite clearly that the current population of the band was the primary determinant in the amount surveyed ultimately. ${ }^{55}$ It should also be noted that the historical record with respect

Ibid.

Ibid. at 159.

Ibid. at 161 .

See correspondence: Forget to Secretary (21 June 1898); Forget to Secretary, Department of Indian Affairs (21 June 1898); Forget to Secretary, Department of Indian Affairs (6 September 1898); Secretary, Department of Indian Affairs to Forget (27 September 1898); Laird to Secretary, Department of Indian Affairs (30 March 1899); Secretary, Department of Indian Affairs, to Secretary, Department of the Interior (13 March 1903), Ottawa, NAC (RG 10, vol. 3935, file 113537-1) [NAC file 113537-1]. The 6 September 1898 letter from Forget is reproduced in the judgment of Gerein J. at trial in Lac La Ronge Indian Band v. Canada (1999) 188 Sask. R. 1, [2000] I C.N.L.R. 245 (Q.B.) (QL) at para. 110. The 27 September 1898 letter to Forget, then Indian Commissioner for the North West Territories, contained the following:

As to the recommendation that the reserve at Nut Lake be extended it is observed that the Agent seems to think it advisable and that you endorse his view, but the Minister is not clear as to the necessity, and would like before taking any action in the matter to have a further report from you as to what, if anything, there is in the circumstances present or prospective of the Indians concerned to render it expedient to make the proposed addition to their Reserve.

In his response dated 30 March 1899, the new Indian Commissioner David Laird stated, with specific reference to the above paragraph, "I beg to say that the addition of 5-9 square miles is required to make up the full quantity of land the Indians of the Nut Lake Reserve are entitled to, taking the number paid at the last annuity payments as the strength of the band" (see NAC file 113537-1, ibid.). The 13 March 1903 letter to the Secretary, Department of the Interior indicated that the Minister had approved the "recommendation made by the Hon. Mr. Laird to the effect that an addition of 5.9 square miles due to the Yellow Quills' band in Treaty 4 be made to their reserve at Nut Lake." It may be observed that David Laird, who within less than three months would address the assembled Indians at Lesser Slave Lake as Treaty 8 Commissioner, interpreted the land entitlement provisions of Treaty 4 as calling for a survey at present population where insufficient reserve lands had been surveyed previously. 
to the Yellow Quill, Cowessess, and Thunderchild Bands, as recounted by Vancise J., indicates clearly that Canada was aware, prior to the making of Treaty 8, that problems of Treaty interpretation were present where it was discovered that insufficient reserve lands had been surveyed initially. The implications of this fact will be examined further below.

\section{Ultimate CONCLUSION IN LAC LA RONGE}

Justice Vancise concluded as follows:

In my opinion, the Treaty, the notes of the negotiations made at the time the Treaties were negotiated, the contemporary writings, and the subsequent conduct of the parties do not support that interpretation [of the trial judge]. I think it is clear from the uniform approach taken to treaty negotiations that Canada intended to adopt the same approach in Treaty No. 6 that it had in the earlier Treaties. In this respect the Robinson Treaties are most important as they indicate an intention to set aside lands for the Indian Bands based upon the population of the Bands at the time of the treaty. There is no reference in any of the treaty documents or in the treaties themselves that the Crown intended, as a general practice, to leave the matter of the allocation of reserve lands open-ended. There is no reference or statement to support an interpretation that the land entitlement would increase as the population of the Band increased. Indeed that was contrary to what Canada wanted - finality in connection with the treaty obligations, so that settlement of the West could proceed. ${ }^{56}$

What is extraordinary about this conclusion is the absence of any reference to the intentions or perceptions of the Aboriginal signatories. Vancise J. focused completely on the historic intentions of Canada with respect to treaty making, without recognizing that all treaties are specific documents involving two parties with intentions and interests that cannot be assumed a priori to coincide.

\section{ApPlication of Legal Principles to Treaty 8}

The interpretative principles outlined in Marshall No. $l$ would appear to be applicable to the interpretation of Treaty 8. The question is whether the decision in Lac La Ronge assists in the interpretation of the land entitlement provisions contained within this latter Treaty. There are three issues which suggest that it does not: interpretative errors on the part of the Saskatchewan Court of Appeal, important textual differences between Treaty 8 and Treaty 6 , and substantial differences from the earlier Numbered Treaties in the historical and cultural context surrounding the negotiation and implementation of Treaty 8.

\section{INTERPRETATION ERRORS IN LAC LA RONGE}

It has been argued above that numerous errors of interpretation are made in the Lac La Ronge decision. These errors in the application of principles for the interpretation of treaties in general render it difficult to rely on the authority of the decision to any great extent in the interpretation of Treaty 8 . Further, while the Supreme Court of Canada did not grant leave to appeal, this does not mean it tacitly upheld the decision or the methodology employed. It could well be that the Supreme Court felt the facts were very specific to the case, and did not have significant national importance at this time. It is suggested, therefore, that the authority 
of Lac La Ronge vis-à-vis an interpretation of the land entitlement provisions of Treaty 8 can be limited to an affirmation that the two-step test laid out by McLachlin J. is the appropriate model to employ.

\section{TEXTUAL DifFERENCES BETWEEN TREATY 8 AND TREATY 6}

The land entitlement provision of Treaty 6 states:

And Her Majesty the Queen hereby agrees and undertakes to lay aside reserves for farming lands, due respect being had to lands at present cultivated by the said Indians, and other reserves for the benefit of the said Indians, to be administered and dealt with for them by Her Majesty's Government of the Dominion of Canada; provided, all such reserves shall not exceed in all one square mile for each family of five, or in that proportion for larger or smaller families, in manner following, this is to say: that the Chief Superintendent of Indian Affairs shall depute and send a suitable person to determine and set apart the reserves for each band, after consulting with the Indians thereof as to the locality which may be found to be the most suitable for them. ${ }^{57}$

\section{The land entitlement provision of Treaty 8 states:}

And Her Majesty the Queen hereby agrees and undertakes to lay aside reserves for such bands as desire reserves, the same not to exceed in all one square mile for each family of five for such number of families as may elect to reside on reserves, or in that proportion for large or smaller families; and for such families or individual Indians as may prefer to live apart from band reserves, Her Majesty undertakes to provide land in severalty to the extent of 160 acres to each Indian, the land to be conveyed with a proviso as to non-alienation without the consent of the Governor-General in Council of Canada, the selection of such reserves, and lands in severalty, to be made in the manner following, namely, the Superintendent General of Indian Affairs shall depute and send a suitable person to determine and set apart such reserves and lands, after consulting with the Indians concerned as to the locality which may be found suitable and open for selection. ${ }^{58}$

There are several significant differences to be observed with respect to the two Treaty provisions.

The first clear difference is the emphasis on "reserves for farming lands" in Treaty 6 , whereas in Treaty 8 it is "reserves for bands." Treaty 6 explicitly recognizes that there may be lands "already cultivated" to which the Crown was to have "due regard." Treaty 8 does not do so, for the clear and sufficient reason that no such lands existed within the Treaty area. Other provisions in Treaty 8 provide for the fact that some bands (and families) may, in the future, elect to "cultivate the soil" or "to raise stock." 59 While it may, therefore, be possible

Supra note 24.

Supra note 2.

The economic benefits provisions of Treaty 8 , ibid. state:

FURTHER, Her Majesty agrees that each Band that elects to take a reserve and cultivate the soil, shall, as soon as convenient after such reserve is set aside and settled upon, and the Band has signified its choice and is prepared to break up the soil, receive two hoes, one spade, one scythe and two hay forks for every family so settled, and for every three families one plough and one harrow, and to the Chief, for the use of his Band, two horses or a yoke of oxen, and for each Band potatoes, barley, oats and wheat (if such seed be suited to the locality of the reserve), to plant the land actually broken up, and provisions for one month in the spring for several years while planting such seeds; and to every family one cow, and every Chief one bull, and one mowing- 
to construe from the text of Treaty 6 that the Indian signatories were already settled or were on their way to becoming settled in the immediate future, it is not possible to make the same construction from the text of Treaty 8 .

The second clear difference is in the land entitlement formula provided by each treaty. Treaty 6 provides a "one-size fits all" entitlement of one square mile for each family of five, or 128 acres per Indian. Treaty 8 , however, not only provides the same acreage entitlement to "such number of families as may elect to reside on reserves," but also provides an entitlement of 160 acres per Indian "for such families or individual Indians as may prefer to live apart from band reserves." This represents a radical change in entitlement between Treaty 6 (and, in fact, all of the preceding Numbered Treaties) and Treaty 8 - a change that was not discussed by the Court in Lac La Ronge.

Taking a closer look at the text itself, land entitlement under Treaty 8 is an individual or family right to choose between contributing to a reserve or reserves in common at 128 acres per individual or family member or to reside apart from such a reserve or reserves, taking lands in severalty at 160 acres per individual or family member. The choice made determines the quantum of land surveyed subsequently. Two specific entitlements are therefore at issue, both of which must be performed in order that the obligation may be said to have been fulfilled completely and properly. First, there is the entitlement due every individual Treaty 8 Indian to be offered the means and opportunity for a full and informed decision between contributing to a reserve or reserves in common and taking lands in severalty. Second, there is the entitlement due every individual Treaty 8 Indian to have lands surveyed sufficient to fulfil their entitlement based upon the selection made.

Two separate and distinct calculations are therefore required, the first to be completed before the second may properly be attempted: a calculation to determine the number of

machine and one reaper for the use of his Band when it is ready for them; for such families as prefer to raise stock instead of cultivating the soil, every family of five persons, two cows, and every Chief two bulls and two mowing machines when ready for their use, and a like proportion for smaller or larger families. The aforesaid articles, machines and cattle to be given once for all for the encouragement of agriculture and stock raising; and for such Bands as prefer to continue hunting and fishing, as much ammunition and twine for making nets annually as will amount in value to one dollar per head of families so engaged in hunting and fishing.

The provision for annual supplies of ammunition and twine represent a promise by the Crown to provide resources to support a lifestyle of hunting, fishing and trapping for so long as the treaty signatories desired to continue such a lifestyle. This provision is reinforced by the protections extended to the Indians with respect to their "usual vocations of hunting, trapping and fishing." As stated by the Treaty Commissioners in their report:

Our chief difficulty was the apprehension that the hunting and fishing privileges were to be curtailed. The provision in the treaty under which ammunition and twine is to be furnished went far in the direction of quieting the fears of the Indians, for they admitted that it would be unreasonable to furnish the means of hunting and fishing if laws were to be enacted which would make hunting and fishing so restricted as to render it impossible to make a livelihood by such pursuits (Canada, Parliament, "Report of the Commissioners for Treaty No. 8" 22 September 1899 in Sessional Papers, No. 14 (1900) at xxxvi [Commissioners Report]).

The provisions related to the supply of implements and cattle were to be provided when a decision was made to take reserves and/or lands in severalty. The general expectation, however, was that the selection of reserves, and any consequent call upon the Crown to supply cattle and implements would occur, if at all, in the future. See below for further discussion on this point. 
individuals desiring to contribute to reserve lands in common, as against the number of individuals desiring to take lands in severalty; and a calculation to determine the quantum of lands to be surveyed subsequently as reserve lands in common (the number of individuals requesting such lands multiplied by 128 acres) and the quantum of lands to be surveyed subsequently as lands in severalty (the number of individuals requesting such lands multiplied by 160 acres). Thus, the Crown cannot assert that it has fulfilled the land entitlement provisions of Treaty 8 by the mere fact that it has surveyed a sufficient quantum of reserve lands in common. It must also establish the further fact that the individual Indians concerned were given the means and opportunity to make a full and informed decision as to whether they did indeed desire to have such reserve lands in common surveyed for them and not lands in severalty.

The third clear difference is in the "deputing" clause. In Treaty 6, a person was deputed and sent out to set apart "suitable" reserve land "for the bands" after consultation with the Indians. Under Treaty 8, a person must still be deputed, but instead sets apart "reserves, and lands in severalty," once consultation occurs "as to the locality which may be found suitable and open for selection." 60 The addition of "may be found ... open for selection" appears to contemplate that non-Aboriginal settlement might interfere with reserve selection, such that the surveyor would have to pay particular attention to non-Aboriginal interests. It is unclear whether it can be assumed, strictly on the face of the treaty, that such interests already existed or if the treaty anticipated such problems in the future. However, as the review of the historical and cultural context below will show, Treaty 8 very much anticipated this problem as a future concern.

Pursuant to Treaty 8 , therefore, the triggering factor with respect to land entitlement is an indication by individual Indians and/or families and bands that they desire to select reserves and/or lands in severalty. There are no explicit or implied time constraints, as it was intended clearly that selections, if made at all, would take place in the future. There is no similar language in the land entitlement provision of Treaty 6 that speaks of the Indians or bands having a right, post-treaty, to elect to take a reserve. By necessary implication, the Indians under Treaty 6 must have made that election when they signed the treaty.

Having regard for the text of each Treaty generally, there is another important textual difference between Treaty 6 and Treaty 8 . While Treaty 6 contains a census provision (something that Vancise J. found to be a significant link back to the Robinson Treaties of 1850), Treaty 8 does not. The annuity provision of Treaty 8 makes no mention of a census being taken, merely that cash will be paid "to said Indians" each year in certain amounts, depending on the rank of each Indian. ${ }^{61}$

6) Supra note 2.

61 Ibid:

Her Majesty also agrees that next year, and annually afterwards for ever, She will cause to be paid to the said Indians in cash, at suitable places and dates, of which the said Indians shall be duly notified, to each Chief twenty-five dollars, and Headman, not to exceed four to a large Band and two to a small Band, fifteen dollars, and to every other Indian, of whatever age, five dollars, the same, unless there be some exceptional reason, to be paid only to heads of families for those belonging thereto. 
Strictly on a "facial" reading of the land entitlement provisions in Treaty 8, therefore, it is clear that they differ significantly from those in Treaty 6 or the Robinson Treaties. It is apparent that the Indians signing Treaty 8 were not acknowledged as having cultivated lands and were very much expected by Canada to continue in their traditional vocations of hunting and fishing. Land entitlement was a right to be exercised in the future, post-treaty, upon the election of individual Indians or families to contribute to reserve lands in common or to take lands in severalty. There is no reference to a census being taken immediately after the making of the Treaty (and for good reason, if there was no immediate need for reserves or for lands to be set aside).

None of the "facial" indicators at play in Lac La Ronge resulting in the "date of first survey" interpretation are apparent in the text of Treaty 8 . The land entitlement provisions of this Treaty, being in their fundamental nature and effect an individual or family right, are inconsistent entirely with the notion of a collective entitlement that is fixed or crystallized at date of first survey. If, indeed, the provisions of Treaty 8 (on a purely textual analysis) are consistent at all with the ruling of the Saskatchewan Court of Appeal, they are so only to the extent that the entitlement may be fixed for those individuals and families actually counted at date of first survey. They cannot be consistent for those individuals and families not counted at that time. Until they are finally counted, in terms of being presented with the opportunity to select between contributing to reserves in common or taking lands in severalty, any natural increase on their part is a legitimate increase to their individual land entitlement (if taken in severalty) or to the land entitlement of the Band on which annuity paylist they may be placed by the Crown (if taken in common). To assert otherwise would be to affirm the possibility for inequality of treatment under the Treaty: one individual or group of individuals could limit or freeze the Treaty rights to land of another individual or group of individuals simply by selecting their reserves or lands in severalty at some earlier point in time. The former would then have benefited from natural increase to their date of first survey, the latter being denied the same benefit due solely to the opportunity and decision of others to exercise their identical Treaty rights sooner.

In the result, and in contrast to the textual analysis of Treaty 6 in Lac La Ronge, the text of Treaty 8 implies clearly that where insufficient lands are set aside initially, any outstanding entitlement is not (indeed, cannot be) fixed or frozen as of this initial date of survey, but must be determined anew when further lands are set aside or the obligation is fulfilled.

HISTORICAL AND CULTURAL CONTEXT SURROUNDING THE NEGOTIATION AND IMPLEMENTATION OF TREATY 8

In step two of the interpretive framework set out by McLachlin J., ambiguities, doubtful expressions, or uncertainties that arise from the text of a treaty are to be examined in light of the historical and cultural context surrounding the making and subsequent implementation of the treaty. Several factors distinguish the context surrounding Treaty 8 from the other Numbered Treaties: the inclusion of the "land in severalty" provision; the fear expressed by the Indians that the Treaty would lead to their confinement on Reserves; the perception on the part of the Treaty Commissioners that there would be no immediate need for the survey of reserve lands and/or lands in severalty; the knowledge possessed by the Crown with respect to difficulties in interpreting the land entitlement provisions of previous Numbered 
Treaties; and the almost complete preponderance of multiple surveys subsequent to Treaty made in accord with the current population formula.

\section{a. Land in Severalty}

The various versions of The Indian Act since 1876 have allowed for individual allotments of existing reserve lands. The possibility of severalty allotments in lieu of reserves in common, however, was debated seriously for the first time prior to the commencement of negotiations on Treaty $8 .^{62}$ The discussion appears to have been prompted by recognized

6.2 The concept and perceived benefits of providing Indian families with individual allotments of land had its origins in the pre-Confederation period. An Act to encourage the gradual civilization of the Indian Tribes in this Province, and to amend the Laws respecting Indians, S.C. 1857, c. 26 [Gradual Civilization Act] stipulated that if a Board of Examiners found an Indian applicant to be literate in either English or French, free of debt, and of good moral character, he could be awarded a plot of Reserve land, the latter thereupon being removed from Band control. The Indian Act, S.C. 1876, c. 18 s. 5-10 [Indian Act] gave authority to the Superintendent General to survey Indian Reserves into individual lots, whereupon Band members could be assigned lots by the Band Council. After noting that Band Councils were proving reluctant to assign individual allotments, an amendment to the Indian Act in 1879 removed the power to allot Reserve lands from the Band Council and gave it to the Superintendent General.

Individuals assigned these lots would receive "location tickets" after having proved they were literate, free of debt, and of good moral character. After a three-year probation period, he would be enfranchised and given full title to the land. Clause 94 of the Indian Act nevertheless excluded from the various enfranchisement provisions (ss. 86-93) all Indians residing in Manitoba and the North-West Territories. The exclusion was repeated in The Indian Act, 1880, as am. by An Act to further amend "The Indian Act, 1880 ," S.C. 1884, c. 27.

The view that private ownership of land is a necessary encouragement to Indian development gathered strength and, by the late 1880 s, a policy was in place to divide Indian Reserves in western Canada into separate farms. Reserve lands were to be subdivided according to section, township and range, as was the case with Dominion Lands. Each section surveyed within a Reserve was, however, to be further subdivided into sixteen lots of forty acres each (one-quarter quarter sections). Section 16 of the Indian Act was amended in 1890 to ensure that no Indian would be granted more than 160 acres, or four 40acre lots, and to provide that, prior to a location of an Indian, the Indian Commissioner for Manitoba and the North-West may issue a Certificate of Occupancy for land that the Indian, with the approval of the Commissioner, may select. The Certificate could be cancelled at any time by the Commissioner and signified nothing more than that the holder had lawful possession against others.

Similar sentiments were in place south of the border. Further to the Dawes Severalty Act of 1887,49 th Cong., 2nd Sess., c. 119, reservations in the United States were to be divided and allotted in severalty on the basis of 160 acres to each head of family. The federal government would hold title in trust for a period of 25 years, during which time the lands could not be sold or mortgaged. For those Indians who failed or refused to select their allotment, the Secretary of the Interior was empowered to make the choice. Once the patent was issued, the new native owner would become subject to the laws of the state or territory in which the land was located. United States citizenship would be granted to those allotted land or to Indians who resided "separate and apart from the tribe" and who had "adopted the habits of civilized life." Reservation lands remaining after allotment to tribal members were to be purchased by the federal government, with Indian consent, the sale price being held in trust for the "education and civilization" of the former tribal members. Congress would later, in 1891, enact legislation permitting the leasing of allotted lands in trust for agriculture, grazing, mining, and lumbering.

Sarah Carter has described the implementation of the Reserve subdivision policy in Canada:

Subdivision surveys of reserves in the North-West began in the summer of 1889 on the Muscowpetung and Crooked Lakes agencies. Portions of the Reserves of Piapot, Muscowpetung, Pasquah, Kahkewistahaw, Sakimay, and O'Soup were subdivided that year and that of Cowessess the next. Many reserves in the Treaty Six district were also subdivided between 1889 and 1892 . Agencies such as the Touchwood Hills and File Hills were not subdivided, although their boundaries were defined and made consistent with the Dominion Lands Survey. In the Treaty 
differences in the conditions and lifestyle of the northern Indians, as opposed to those covered by treaties in the south. By 1898, it is apparent that the Department of Indian Affairs was considering the possibility of land in severalty as a term within future "northern" treaties (the first of which became Treaty 8), as opposed to the general approach of reserve lands in common provided to the Indians in the "south":

\begin{abstract}
The question of allotting Reserves is a difficult one to deal with, without definite knowledge of local conditions, but it is probable that these Northern Indians, equally with those of the South, will desire to be granted lands for their sole use and occupancy and while for many reasons it would be well could the Reserve system be dispensed with and ownership in severalty be substituted in future Treaties, I fear that in consideration of the need of educational and religious facilities it will be necessary still to adhere to the plan of assembling the Indians upon Reserves. ${ }^{63}$
\end{abstract}

As a passage from an 1899 letter to the Superintendent General of Indian Affairs indicates, the government expected a very differently organized group of Indians in the north from those it had been dealing with in the south:

From what I have been able to learn of the North country, it would appear that the Indians there act rather as individuals than as a nation, and that any tribal organization which may exist is very slight. They live by hunting and by individual effort, very much as the halfbreeds in that country live. They are averse to living on reserves; and as that country is not one that will ever be settled extensively for agricultural purposes it is questionable whether it would be good policy to even suggest grouping them in the future. The reserve idea is inconsistent with the life of a hunter, and is only applicable to an agricultural country. The most the Indians are likely to require in the way of reserves are small fishing stations at certain points which they might desire to have secured to them. I do not think the Commissioners should go further in the way of general reservations, unless they should find that circumstances compel them. But they should have authority to guarantee to every Indian settled upon, or in occupation of land, an individual title thereto. The limit might be put at 160 acres as the Indians are likely to require very small holdings. ${ }^{64}$

Furthermore, the "North country" itself was not considered as conducive to agriculture as were lands in the south:

Since Treaty Three, the Dominion in all treaties with the Indian has undertaken to pay $\$ 5$ a year to each Indian in perpetuity, and $\$ 15$ to headmen and $\$ 25$ to Chiefs. Now the question arises: if this was considered a fair money compensation for the land in Manitoba and the organized territories, what would be a fair compensation for the land in the territory now to be treated for. The former land was admirably suited for

Four district, subdivision proceeded only on those reserves that were close to the railway and were attractive for agricultural purposes (Lost Harvests: Prairie Indian Reserve Farmers and Government Policy (Montreal: McGill-Queen's University Press, 1993) at 205.)

Carter notes further, however, that enthusiasm for the policy apparently was short-lived:

It appears that after the early 1890 s the concerted program of subdividing parts of reserves into forty-acre lots ended. After the change of government in 1896, subdivisions were generally surveyed only after land was surrendered for the purposes of sale. Officials saw no need to subdivide reserves where surrenders were refused. The rationale for the early subdivisions, that they were in the agricultural interests of the Indians, was dropped (ibid. at 209.) 
agriculture. Its settlement was necessary for the real making of the Dominion. The building of the transcontinental railway made the wiping out of the Indians title urgent, and the changing condition interfered with the Indians means of livelihood and mode of life. There were, therefore, good reasons for giving them the maximum compensation. The latter land is not of appreciable value agriculturally. There is no urgent public need of its acquirement. There may be mineral development and some consequent settlement in spots, but this will not bring sudden or great changes likely to interfere to any marked degree with the Indian mode of life and means of livelihood. I think it would not be illiberal to answer the question by saying that half the amount which we agreed to pay under the former treaties would be ample compensation for the Indians who are to be parties to the proposed one. ${ }^{65}$

The final decision on how to proceed with negotiating what became Treaty 8 was settled, with respect to reserves, as follows:

As to Reserves, it has been thought that the conditions of the North country may make it more desirable to depart from the old system, and if the Indians are agreeable to provide land in severalty for them to the extent of 160 acres to each, the land to be conveyed with a proviso as to non-alienation without the consent of the Governor General in Council. Of course, if the Indians prefer Reserves you are at liberty to undertake to set them aside. ${ }^{66}$

Clearly, the differing social organization of the northern Indians, the lack of suitability of northern lands for agricultural purposes, the lack of an urgent public need to acquire these northern lands for settlement, and the minimal anticipated effect of non-Aboriginal settlement on the traditional Aboriginal way of life were significant factors leading to the inclusion in Treaty 8 of the land in severalty provision, thereby differentiating the land entitlement provisions of this treaty significantly from Treaty 6 and the previous Numbered Treaties made to the south.

\section{b. Fear of Confinement to Reserves}

The primary finding of fact made by Vancise J. in Lac La Ronge was that "the common intention of the parties [to Treaty 6 ] at the time the treaties were negotiated and executed and at the time of the signing of the Adhesion Agreement was that the parties intended to carry out the selection and survey soon after the date of signing of the Treaty and the Adhesion Agreement. ${ }^{167}$ A necessary implication of this conclusion would appear to be that it was the desire, or at least the intention, of the Indian signatories to settle on reserves almost immediately. The historical facts indicate clearly, however, that no such desire or intention can be attributed to the Indian signatories to Treaty 8. As noted in the Report of the Commissioners,

the Indians were generally averse to being placed on reserves. It would have been impossible to have made a treaty if we had not assured them that there was no intention of confining them to reserves. We had to very

(6) Correspondence, Superintendent General of Indian Affairs to Laird, McKenna, and Ross (12 May 1899), Ottawa, NAC (RG 10, ibid.).

6. Lac La Ronge, supra note 3 at para. 154. 
clearly explain to them that the provision for reserves and allotments of land were made for their protection, and to secure to them in perpetuity a fair portion of the land ceded, in the event of settlement advancing. ${ }^{68}$

\section{c. No Expectation of Immediate Settlement on Reserves}

The Treaty Commissioners reported on the unlikelihood that the signatories to Treaty 8 would settle on reserves immediately after taking treaty:

As the extent of the country treated for made it impossible to define reserves or holdings, and as the Indians were not prepared to make selections, we confined ourselves to an undertaking to have reserves and holdings set apart in the future, and the Indians were satisfied with the promise that this would be done when required. There is no immediate necessity for the general laying out of reserves or the allotting of land. It will be quite time enough to do this as advancing settlement makes necessary the surveying of the land. Indeed, the Indians were generally averse to being placed on reserves. ${ }^{69}$

The forward-looking nature of the land entitlement provisions of Treaty 8 and the intention that reserves and lands in severalty be surveyed when requested by the Indians is illustrated in the Commissioner's Report on the adhesions taken in 1900:

As was reported by your commissioners last year, there is little disposition on the part of most of the northern Indians to settle down upon land or to ask to have reserves set apart. Dealing, under your instructions, with demands for land, two small provisional reserves were laid out at Lesser Slave Lake, for Kinoosayo's band, and fifteen or sixteen applications were registered for land in severalty by the Indians who have already, to some extent, taken to agriculture. ${ }^{70}$

The evidence is therefore clear that the parties to Treaty 8 had no intention that reserve lands in common and/or lands in severalty be selected and surveyed for all individuals and bands within a short time after signing the Treaty. Furthermore, it is equally clear that the parties did intend that reserves and/or severalty lands would be selected and surveyed as needed, and when requested, by the Indians. Finally, for most of the Indian signatories, it was anticipated that such selections and surveys would take place, if at all, in the future.

This contextual point is of considerable importance given the conclusion made by Vancise J. in Lac La Ronge that entitlement to land pursuant to Treaty 6 is fixed or crystallized at date

68. Commissioners Report, supra note 59 at xxxvii [emphasis added].

69 Ibid.

70 Canada, Parliament, "Annual Report of the Department of Indian Affairs for the Year Ended June 30, 1900, Report of the Commissioner for Treaty 8, 11 December 1900" in Sessional Papers, No. 14 (1901).The Report noted further:

It appears that this disinclination to adopt agriculture as a means of livelihood is not unwisely entertained, for the more congenial occupations of hunting and fishing are still open, and agriculture is not only arduous to those untrained to it, but in many districts it as yet remains untried. A consequence of this preference of old pursuits is that the government will not be called upon for years to make those expenditures which are entailed by the treaty when the Indians take to the soil for subsistence.

By Order-in-Council dated 2 March 1900 (P.C. 460), J.A. Macrae had been appointed Indian Commissioner and charged with the task of securing further adhesions to Treaty 8 at Fort St. John and Fort Resolution on Great Slave Lake. In the event, he also took adhesions from the Crees of Sturgeon Lake, and the Slaves of Upper Hay River. 
of first survey. This assumption is grounded primarily on his finding, noted above, that the parties intended the selection and survey of reserve lands to take place soon after the signing of the treaty. ${ }^{71}$ Indeed, it is this particular finding of common intention that serves to distinguish the conclusion of the Saskatchewan Court of Appeal from the ruling of the court below. ${ }^{72}$ The emphasis on determining common intention springs directly from the adoption by the Court of the two-step model for the interpretation of treaties set out by McLachlin J. in Marshall No. $1{ }^{73}$ It is, in this sense, the necessary and primary basis upon which a final interpretation of the text is to be made. Implicit, however, in this method of analysis, in the contrary findings of common intention made by the Court of Appeal and by Gerein J. for the Court of Queen's Bench, and in the contrary conclusions arrived at by the two Courts based primarily on those findings, is the fact that both findings cannot lead to the same conclusion. ${ }^{74}$ In other words, the stronger the implication between the common intention and the ultimate interpretation attached to the text of Treaty 6 , the more inconsistency there must be if a similar interpretation of the text is based upon an opposing or contrary common intention. If this is to be accepted and if it is recognized that no common intention existed between the parties to Treaty 8 that lands be surveyed soon after the signing of the treaty, it is submitted that there can be no immediate application of the conclusion in Lac La Ronge that land entitlement is to be fixed at date of first survey. This is especially so if it is to be accepted further that the primary basis for this latter conclusion was that the common intention of the parties to Treaty 6 was that lands be surveyed soon after the parties signed that treaty. Indeed, if it is recognized that the common intention of the parties to Treaty 8 was more in line with the conclusion reached by Gerein J. with respect to Treaty 6 (that the parties saw the creation of reserves as a future event, with no time constraints), then it would appear that the parties to Treaty 8 intended clearly that land entitlement would be calculated as of the date when the treaty obligation was fulfilled (the current population formula). ${ }^{75}$

71 Lac la Ronge, supra note 3 at para. 153: "An interpretation which fixes the land entitlement at the date of first survey, subject to certain adjustments to permit the admission of later adherents, is the interpretation that best accords with the common intention of both parties."

72 Ibid. at para. 145 :

The trial judge found the parties intended that the creation of reserves was to be a future event with no time constraints. The creation of reserves would happen in due time and the parties would deal with the land entitlement when it arose. He concluded that the parties to Treaty No. 6 intended that the land entitlement would be calculated at the time when the treaty obligation was fulfilled not when the reserve land was first set aside.

73. Ibid. at para. 43: "the Court's task is to determine the meaning of the land entitlement provisions of Treaty No. 6 as based upon the shared intention of the parties at the time the treaty was signed."

74 There would appear to be little reason for the Saskatchewan Court of Appeal to have distinguished its finding of common intention from that made by Gerein J. if the common intention that reserve creation would be a future event, with no time constraints, and if the common intention that reserves be surveyed soon after the signing of the treaty both imply the conclusion that the parties to Treaty 6 intended for land entitlement to be fixed at date of first survey. If the conclusion is the same in either case, the error by Gerein J. would have been one of reasoning, rather than of law.

75 Bell \& Buss, supra note 16 at 691 , reach a somewhat different, though not necessarily contradictory, conclusion:

adopting Justice Binnie's model of implied rights, one could address the silences in the land and severalty clause by implying a modern TLE formula for calculation of the reserve land shortfall at the DOFS based on the general objectives of protection, security, and providing a fair portion of land to sustain a lifestyle that helps the Indian signatories of Treaty 8 maintain economic selfsufficiency. What is important in this interpretation is not so much the silence of the treaty, but the fact that it is forward looking with respect to setting aside land, and that land is to be set aside to accomplish a specific purpose understood by both the Indians and the Crown. Neither party 


\section{d. Difficulties in the Interpretation of Land Entitlement}

Provisions in Previous Numbered Treaties

As noted above, Canada had prior knowledge of interpretive problems arising from the wording of the reserve land provisions in previous Numbered Treaties in cases where it was discovered that insufficient lands had been surveyed initially. This fact is confirmed by the historical record recounted in Lac La Ronge with respect to the Yellow Quill, Cowessess, and Thunderchild Bands.

As the sole drafter of Treaty 8 , Canada could therefore easily have made specific reference to this possibility in the treaty text so as to avoid all possible subsequent confusion on the matter. It chose not to do so. If clarity of meaning could have been secured and recognized difficulties of interpretation avoided in the future, it is submitted that the party that should assume the risk is the party that was aware of the problem, yet chose to maintain an existing situation of potential uncertainty. The situation is similar to that involved in the interpretation of insurance contracts ${ }^{76}$ and "contracts of adhesion," 77 where there is little or no opportunity for one party to clarify ambiguous terms. In both cases, the law recognizes that it is the drafter who should assume the risk of any ambiguity or uncertainty.

By failing to clarify potential uncertainties in the land entitlement provisions of Treaty 8 , Canada is now claiming the benefit of the existing silence/ambiguity/uncertainty that it recognized prior to the negotiation of Treaty 8 had created difficulties of interpretation in previous treaties. If it is to be accepted, per Justice Cory in Badger, that "any ambiguities or doubtful expressions ... must be resolved in favour of the Indians, ${ }^{, 78}$ even in cases where such uncertainties, ambiguities, or doubtful expressions may be entirely unintended, it must be clearer still that they should be resolved in favour of the Indian signatories where they could have been easily avoided, on the basis of past experience, by the party drafting the treaty.

anticipated time restrictions on the date this objective would be fulfilled, the complications arising from inaccurate and multiple surveys, inconsistency in the application of federal policy, confusion in the pay list counts, and questionable scrip practices. The honour of the Crown requires that these unanticipated events be resolved in favour of the signatories to Treaty 8 , and in a way that fulfills oral terms not included in the written text. This may mean implying a right to a land base sufficient in size to enable the contemporary band to survive as an economically self-sufficient entity, regardless of who was or was not on the pay list at the DOFS, and regardless of who did or did not take scrip.

See Craig Brown \& Julio Menezes, Insurance Law in Canada, 2d ed. (Toronto: Carswell, 1991) at 127: "The basis for that rule [contra proferentem] in general contract theory is that the burden of irreducible ambiguity should fall on the drafter." See also Nicholas Legh-Jones, ed., MacGillivray on Insurance Law, 9th ed. (London: Sweet and Maxwell, 1997) at 279: "It has been said that a party who proffers an instrument cannot be permitted to use ambiguous words in the hope that the other party will understand them in a particular sense and that the court which has to construe them will give them a different meaning." 


\section{HISTORY OF RESERVE ALLOCATION UNDER TREATY 8}

The historical record of reserve allocation under Treaty 8 contains several examples of multiple surveys. This history shows that the date of first survey formula, as articulated by the Saskatchewan Court of Appeal in Lac La Ronge, was never applied.

There have been seven multiple surveys in Treaty 8: Kinoosayo's Band (current Driftpile, Sucker Creek, Swan River, Sawridge and Grouard First Nations), ${ }^{79}$ Beaver Band of Horse Lake (current Horse Lake First Nation) ${ }^{80}$ Tall Cree Band (current Tall Cree First Nation), ${ }^{81}$ Janvier Band (current Janvier First Nation), ${ }^{82}$ Wabasca Band (current Bigstone Cree Nation), ${ }^{83}$ Little Red River Band (current Little Red River Cree First Nation), ${ }^{84}$ and Slaves of Upper Hay River (current Dene Tha' First Nation). ${ }^{85}$ There is also one instance where, subsequent to an initial survey and a subsequent survey at current population, additional lands were later selected and reserved temporarily, but were never set aside for the use and benefit of the Band (Tall Cree First Nation). ${ }^{86}$

Of these seven examples, four were in explicit accord with the current population formula (Horse Lake, Tall Cree, Little Red River and Dene Tha'), one included natural increase and decrease over the period between the date of first survey and the date used as the basis for calculating the amount of additional land surveyed subsequently (Janvier), one approximated more closely the current population formula than the DOFS formula (Kinoosayo's Band), and one was a survey of an area of land to meet immediate needs (in part fulfillment of a calculated entitlement based upon the shortfall at date of first survey and the amount required to fulfill the entitlement of non-Treaty Indians who had since the initial survey joined the band), subsequent to which a recommendation was made to fulfil the still outstanding entitlement at current population (Bigstone). The example of Horse Lake also serves to

See Ottawa, NAC (RG 10,vol. 3959, file 141977-6; RG 10, vol. 4019, file 279393-8; RG 10, vol. 7777, file 27131-1; RG 10, vol. 7777, file 27131-5; RG 10, vol. 7778, file 27131-6; RG 15, vol. 812, file 598921; RG 2, vol. 866, file 842D (Order-in-Council (O.I.C.) 1, 8 January 1904); RG 2, vol. 1071, file 854E (O.I.C. 2144, 13 August 1913); RG 2, vol. 1320, file 638F (O.I.C. 2505, 18 December 1922); Department of Indian Affairs and Northern Development [DIAND] file 777/30-2-150, vol. 1; DIAND file 777/30-3-150A, vol. 1; DIAND file 777/30-6, vol. 1; DIAND file 777/30-24, vol. 1). See Ottawa, NAC (RG 10, vol. 4019, file 279393-8; RG 10, vol. 4019, file 279393-9; RG 10, vol. 4065 , file 412786-3; RG 2, vol. 929, file 1666D (O.I.C. 917, 3 May 1907); RG 2, vol. 1245, file 88F (O.I.C. 936, 29 April 1920); DIAND file 777/30-8, vol. 1; DIAND file 777/30-8-152, vol. 1; DIAND file 777/30-8-152B, vol. 1).

See Ottawa, NAC (RG 10, vol. 4019, file 279393-7; RG 10, vol. 4019, file 279393-8; RG 10, vol. 7777 , file 27131-1; DIAND file, 775/30-1, vol. 1; DIAND file 775/30-2-162, vol. 1; DIAND file 775/30-4, vol. 1; DIAND file 775/30-4-163, vol. 1; DIAND file 775/30-4-187). See Ottawa, NAC (RG 10, vol. 4065, file 412786-4; DIAND file 779/30-13-194, vol. 1).

See Ottawa, NAC (RG 10, vol. 4019, file 279393-8; RG 10, vol. 4019, file 279393-9; RG 10, vol. 7777, file 27131-1; RG 10, vol. 7778, file 27131-17; RG 2, vol. 2220, file 675H (O.I.C. 1958-931, 4 July 1958); DIAND file 775/30-1, vol. 1; DIAND file 777/30-17, vol. 1). See also Indian Claims Commission, Bigstone Cree Nation Treaty Land Entitlement Inquiry, March 2000.

See Ottawa, NAC (RG 10, vol. 4019, file 279393-7; RG 10, vol. 4019, file 279393-8; RG 2, vol. 1158, file 906 (O.I.C. 1501, 9 June 1914); RG 2, vol. 2330, file 1491 (O.I.C. 1965-1312, 23 July 1965); RG 2, vol. 2331, file 1541 (O.I.C. 1965-1449, 11 August 1965); DIAND file, 775/30-1, vol. 1; DIAND file 775/30-2-162, vol. 1; DIAND file 775/30-2-215, vol. 1). See Ottawa, NAC (RG 10, vol. 7777, file 27131-1; DIAND file 775/30-1, vol. 1; DIAND file 775/30-3207, vol. 1; DIAND file 775/30-3-212, vol. 1). 
indicate that use of the current population formula was not always of benefit to the band concerned, as this band would have received more land if their subsequent survey had been in accord with the date of first survey calculation on which current policy is based.

The historical record with respect to the subsequent conduct of the parties to Treaty 8 is therefore most consistent with an interpretation of the land entitlement provisions as being based on the current population formula. In no instance was any subsequent survey in clear accord with the position that land entitlement of the band had been fixed at date of first survey. The practice of the Department with respect to Treaty 8 was, therefore, consistent entirely in what it did not do. It is clear from the historical record that land entitlement was not fixed at date of first survey. If it was the common intention of the parties to Treaty 8 that land entitlement be fixed at date of first survey, whether or not sufficient lands were selected and surveyed at that time, there is no historical evidence to indicate that this intention was ever acted upon where the opportunity to do so presented itself.

\section{Summary OF Principles APPLICABle to TREATy 8}

Below, in summary form, are the primary points to be taken from the discussion above. Taken together, they point clearly to an interpretation of the land entitlement provisions of Treaty 8 that is in accord with the current population formula.

- $\quad$ Pursuant to Treaty 8, land entitlement could be selected and held either in common or in severalty. This was an acknowledged departure in policy from the previous Numbered Treaties in the south and east for reasons specific to the "north" country (the differing social organization of the northern Indians, the lack of suitability of northern lands for agricultural purposes, the lack of an urgent public need to acquire these northern lands for settlement, and the minimal anticipated effect of nonAboriginal settlement on the traditional Aboriginal way of life).

- The land entitlement provisions of Treaty 8 , being in their fundamental nature and effect an individual or family right, are inconsistent entirely with the notion of a collective entitlement that is fixed or crystallized at date of first survey.

- The triggering factor with respect to land entitlement under Treaty 8 is an indication by individual Indians and/or families and bands that they desire to select reserves and/or lands in severalty. There are no explicit or implied time constraints, as it was intended clearly that these selections, if made at all, would take place in the future as needed. The parties to Treaty 8 had no common intention or expectation that reserves or lands in severalty would be selected and surveyed within a short time after signing the treaty. As such, the primary justification for the crystallization of land entitlement at date of first survey in the decision of the Saskatchewan Court of Appeal in Lac La Ronge (that the common intention of the parties to Treaty 6 was that reserve lands be surveyed soon after the signing of the treaty) is not present with respect to Treaty 8 .

- The Crown had prior knowledge of interpretive problems arising from the wording of the reserve land provisions in previous Numbered Treaties. It therefore could 
have easily drafted the relevant provisions of Treaty 8 so as to avoid all possible subsequent confusion on the matter. That it did not do so must be at its own peril. If clarity of meaning could have been secured and recognized difficulties of interpretation avoided in the future, the party that should assume the risk is the party that was aware of the problem, yet chose to maintain an existing situation of potential uncertainty.

- The historical record with respect to the subsequent conduct of the parties to Treaty 8 is consistent entirely with an interpretation of the land entitlement provisions as being based on the current population formula. In no instance was any subsequent survey in clear accord with the position that land entitlement of the band had been fixed at date of first survey.

In the result, the text, the historical and cultural context with respect to the negotiation of the treaty, and the subsequent conduct of the parties all support the conclusion that, where insufficient lands are set aside initially, the land entitlement provisions of Treaty 8 are to be interpreted such that the entitlement is not fixed or frozen as of this initial date of survey. Instead, they must be determined anew by reference to current population, when further lands are set aside.

It may also be concluded from the discussion above that essential factors involved in the interpretation of Treaty 8 can be distinguished from the analysis of Treaty 6 in Lac La Ronge. Furthermore, enough doubts have been raised as to the legal soundness of the decision to question the applicability of its ratio too widely. Lac La Ronge should not, therefore, be held as authority for much beyond the fact that it is permissible in the analysis of treaty land entitlement to use the two-step analysis set out by McLachlin J. in Marshall No. 1.

\section{Treaty Land Entitlement and Federal Policy}

This section of the article will address current federal policy with respect to treaty land entitlement. Implicit assumptions underlying the policy are identified and analyzed. The policy is then assessed in light of the land entitlement provisions of Treaty 8 discussed and defended above. It is argued that current treaty land entitlement (TLE) policy serves to reduce unilaterally and arbitrarily the obligations assumed by Canada under this Treaty. The suggestion is then made that the discrepancy between policy and actual obligation should be reduced by a move to the current population formula called for under Treaty 8 . Short of this, however, principled reasons are identified that support a broadening of various elements in the adjusted date of first survey (ADOFS) calculation.

\section{A. Current federal Policy on Treaty land Entitlement}

\section{SUMmary OF POLICY}

As noted previously, current federal policy on TLE is based on determining a population figure for the band as of the date reserve lands are first surveyed for them. To this figure are added what are called late additions or certain restricted categories of eligible individuals 
who join the band after its date of first survey. The number so determined is referred to as the ADOFS.

An ADOFS calculation includes the base treaty annuity paylist figure for the year reserve lands are first surveyed, arrears (Treaty Indians absent at date of first survey (DOFS), but who appear on a paylist subsequent to that date and were paid arrears for the year of first survey), absentees (Treaty Indians not on the DOFS paylist, but who appear on a paylist for the band before and after DOFS), any subsequent late adherents to treaty (individuals bound by and eligible to receive the benefits of treaty who had yet to appear on any paylist or had yet to be included in any TLE calculation), and any subsequent transfers from landless bands (individuals who had never been counted towards the TLE of any other band who transfer to a band who had received land). Subtracted from this figure are any double counts (individuals and/or their descendants who have received lands previously with another band) and scrip recipients (individuals and/or their descendants who had taken scrip). Canada thus views its lawful obligation as being triggered only when a shortfall at date of first survey, as defined above, is specified and proven, and as being restricted to supplying only the difference between the shortfall so identified and the amount of lands already surveyed for the band. ${ }^{87}$

Below, in summary form, are the elements of the calculation required pursuant to current policy:

Adjusted Date of First Survey Population

$=$

Base Paylist

$+$

Arrears

$+$

Absentees

$+$

Late Adherents

$+$

Landless Transfers

Double Counts

Scrip Recipients

It may be stated that actual settlements negotiated between Canada and the various First Nations who have qualified claims based on the shortfall requirements of the policy have never been restricted to the mere difference between the determined shortfall and the lands already surveyed. While Canada has insisted that any settlement include a component of land at least equal to this shortfall, additional lands and/or money have been provided for various reasons unrelated to its perceived legal obligation to reach a negotiated settlement (in exchange for which Canada has demanded a full release from any further obligation). For the present, however, Canada has been unwilling to accept any claim for negotiation that does not prove to its satisfaction a shortfall determined in accord with its current policy on TLE. 
Permissible inclusions and exclusions within these categories are defined pursuant to specific criteria determined by Canada. The Validation Criteria and Research Guidelines for Treaty Land Entitlement states the following with respect to landless transfers:

An individual will be counted with the first band the individual joined, that already had reserve land set aside (this is referred to as the "portability rule"). The effective date of transfer to the new band is the date an individual actually appears on the annuity paylist or membership list. An exception to this rule occurs when a woman ceased to be a member of her own band upon marriage to a member of another band, pursuant to the Indian Act of the day. In this case, the woman is considered to have become a member of her husband's band upon the actual date of marriage. Where no evidence is available as to the actual date of marriage, reference may be had to the date the woman's name actually appears on the annuity paylist or membership list. $^{88}$

\section{It is noted later under the heading "Clarifications":}

In order to avoid the difficulties posed by the transferring of individuals between bands (due to the historic reality of the frequent movement of individuals) an individual's ability to be included towards a band's TLE ends when the individual joins a band that has already had reserve land set aside.

The rule is designed to prevent "late additions" from being counted more than once. This rule will be followed strictly unless the result is inequitable, as determined on a case by case basis. For example, if a family transferred to one band that already had reserve land set aside, normally they would be counted with the collective. However, if they then transferred to yet another band, after a short period of time and settled permanently with the second band, it may be more appropriate for them to be included with the latter band. ${ }^{89}$

The following is stated under the heading "Exclusions":

a) The following people are excluded from the TLE calculation to prevent "double counts":

1) anyone who has already been included in the calculation of another band's TLE or alternatively has a paternal ancestor who has already been included in the calculation of a band's TLE;

2) and anyone who has taken scrip or severalty or who has a paternal ancestor who took scrip or severalty, before they were born or of the age of majority. However, anyone who took scrip after the DOFS, is not removed from the DOFS paylist count.

b) Indians from outside the treaty area who joined after 1951, when the Indian Register was created under the Indian Act, will be excluded.

c) Non-aboriginal individuals are not included.

d) Individuals or families whose names were entered in error or fraudulently. 
e) Natural increases (i.e. births) among the population listed on the band's DOFS paylist, including any natural increases of absentees or arrears.

f) Offspring of a "late addition" who were born after the date the "late addition" appeared on a paylist of a band that had reserve land. ${ }^{90}$

It is readily apparent that many of the above exclusions are entirely arbitrary and consistent to the extent only that they serve to limit the lawful obligation of Canada. In the result, certain of these exclusions are unacceptable, either as related specifically to the obligations assumed by Canada pursuant to the land entitlement provisions of Treaty 8 or as related to more general legal and historical principles.

Nonetheless, the Government of Canada continues to base its policy upon the principle that the TLE of any band "crystallizes" at date of first survey, in that the entitlement is fixed as of that date and cannot be increased absent permissible adjustments per the ADOFS calculation. The policy appears to be based primarily upon the terms and historical context associated with the making and implementation of the land entitlement provisions of Treaties $1-7$.

\section{ANALYSIS OF ASSUMPTIONS INHERENT TO THE POLICY}

The federal government's justification for its ADOFS policy relies on two assumptions: first, that the right to land entitlement is collective in nature; and second, that it was the common intention of Canada and the Indian bands concerned that reserve lands be surveyed and set apart within a reasonable time after the negotiation of the treaty, based on the thenexisting population. The former position was the explicit philosophical rationalization for the policy statement issued by former Minister Irwin in February 1995, which did not accept the inclusion of late adherents to treaty and transfers from landless bands in an ADOFS calculation. ${ }^{91}$ Current policy, as reflected in the Validation Criteria and Research Guidelines, while accepting the inclusion of these categories of late additions, remains an operational extension of the constituent elements in the asserted collective right. The latter position was argued by Canada and accepted by the Saskatchewan Court of Appeal in Lac La Ronge. Neither justification is applicable to Treaty 8.

9 Ibid.

91 The position was outlined in a letter from Irwin to the Indian Claims Commission dated 23 February 1995:

Canada's position is that it has an outstanding TLE legal obligation only if a claimant First Nation did not receive sufficient land, based on a DOFS [Date of First Survey] population comprising its base paylist, absentees and arrears. This is the threshold test for an outstanding legal obligation with regard to TLE claims. Other categories such as landless transfers, late adherents and so on, may be considered only where a DOFS shortfall has been established and then only if the settlement negotiations have brought these categories into play as in the 1992 Saskatchewan Framework Agreement (Correspondence, Minister of Indian Affairs and Northern Development to Commissioner Daniel J. Bellegarde, Indian Specific Claims Commission (23 February 1995), reprinted in (1995) 3 I.C.C.P. 321 at $321-22$ ). 
a. The Assumed Collective Nature of the Right

The principle that TLE claims in general are based on the assertion of collective rights granted to individual First Nations assumes that there is a sufficient similarity in the applicable land entitlement provisions of the Numbered Treaties. As discussed above, however, this principle is entirely inconsistent with the land entitlement provisions of Treaty 8 , which provide an individual right to choose between residing on a reserve, contributing 128 acres per family member or residing apart from a reserve, taking lands in severalty at 160 acres per family member. The choice made determines the quantum of land subsequently surveyed. For Treaty land entitlement purposes, any "collective" entitlement can arise only when specific individual Indians and families choose to live together and take reserve lands in common. ${ }^{92}$

Bell \& Buss, supra note 16 at 684 state:

Treaty 8 clearly anticipates at least two streams of Treaty 8 Indians in the event that land is set aside for reserves: those who choose to live with a larger group on reserve land and those who do not. One is not less of a "treaty Indian" than the other; the two groups simply have different treaty rights in relation to land because of the election made under the land and severalty clause.

They continue at 685 :

As suggested earlier, the text of Treaty 8 points to a dual stream of Treaty 8 rights: rights associated with land in severalty and rights associated with reserve land. Land in severalty is a right exercisable by individuals. On election of land in severalty, other treaty rights remain available to the individual, such as hunting and trapping, rights and annuities. Other rights in the treaty, such as the provision of livestock and farming implements, are connected to an election to live in a community on reserve land. In this sense, the rights in Treaty 8 are both individual and collective.

While it is apparent that Treaty 8 provided for the choice between contributing to reserves in common and taking lands in severalty, it is unlikely that the Treaty intended there to be a differing stream of rights attached to the choice made. The relationship between lands in severalty and the agricultural benefits provisions of the treaty was addressed in an exchange of correspondence that took place in late 1900. The following is taken from a letter addressed to the Secretary, Department of Indian Affairs, from J.A. Macrae, Inspector of Indian Agencies and Reserves, dated 27 November 1900:

2nd. As to the rights of those taking land in severalty to receive implements, stock, \&c. In the first paragraph providing for such benefits as these are to be supplied to "each Chief of a Band that selects a reserve" and in the second paragraph to "each Band that elects to take a reserve and cultivate the soil" and members thereof. It is generally understood that Indians taking land in severalty are to receive exactly the same benefits as those who take land in a reserve, and that the moment at which they become entitled to those benefits which are intended for the promotion of agriculture, is the one at which they commence to cultivate their land taken in severalty (Correspondence, Macrae to Secretary, Department of Indian Affairs (27 November 1900), Ottawa, NAC (RG 10, vol. 3564, file 82, pt. 21).

The questions were forwarded to Indian Commissioner David Laird, who replied in a letter dated 5 December 1900:

2nd. The paragraphs in the Treaty as to the rights of those taking land in severalty to receive implements, stock, \&c.. and in particular, if they receive them, when the distribution is to be made, are not quite as clear as they might have been; yet the words "for every family so settled", show that in the distribution to be made all are to be treated alike. When an Indian who selects and settles upon land in severalty (which is his reserve) is prepared to cultivate the soil or keep stock, he is entitled to receive the articles promised. There may be some difficulty about bulls, as these are furnished to the Chiefs alone; but the Treaty should not be interpreted too strictly in that regard - two or three families settled near together in severalty might be allowed to have one.

In short, Mr. Macrae has correctly summarised the intention of the Treaty on the $2 \mathrm{nd}$. Point which he has raised when he says: "It is generally understood that Indians taking land in severalty are $t_{0}$ receive exactly the same benefits as those who take land in a reserve, and that the moment at which they become entitled to those benefits which are intended for the promotion of agriculture, is the one at which they commence to cultivate their land taken in severalty" (Correspondence, I aird $t()$ 
While the Treaty provides for reserve lands in common should collectives form and request such lands, the right itself is not restricted to, or a benefit exclusively for, such collectives or bands. Every Indian who adhered or adheres to Treaty 8 secured or secures, therefore, a specified entitlement to land, whether as a member of a band or as an individual claiming lands in severalty. There can be no conceptual difficulty with an individual opening up an unsatisfied individual right. ${ }^{93}$ The assertion that the entitlement to land is only a collective right can be refuted by stating the simple fact that it is entirely possible, in principle, for the Crown to have fulfilled its obligations pursuant to the land entitlement provisions of Treaty 8 without surveying any reserve lands in common whatsoever.

Considerations similar to these may have prompted the Federal Government to adopt its current TLE policy, as reflected in the Validation Criteria and Research Guidelines, wherein individual late adherents to treaty and individual transfers from landless bands are once again permissible elements of a date of first survey shortfall calculation. It is apparent, however, that this modification in policy was an expansion of the constituent elements of the asserted collective right, not an abandonment or reconsideration of the premise itself.

To the extent that the position held by Canada that its obligation to provide land for the Indians and First Nations of Treaty 8 "crystallizes" at date of first survey depends upon the view that TLE is solely the collective right of a band (as, and if, determined for administrative purposes by Canada) and not the right of individual Indians. It is therefore inconsistent with, and inapplicable to, the land entitlement provisions of Treaty 8.

\section{b. The Assumed Common Intention of the Parties}

The assumption of Canada with respect to the Numbered Treaties generally appears to be that the Crown did not intend, and the bands did not expect, that there would be any significant delay between the signing of the Treaties and the initial survey of reserve lands. This assumption carries with it the implication that it was the desire or at least the intention of the Indian signatories to settle on reserves almost immediately. As examined previously, however, the parties to Treaty 8 had no such common intention or desire. The parties here intended clearly that the survey of reserve lands and/or lands in severalty would occur, if it would occur at all, in the future and as needed, in the event that settlement advanced and the Indians desired to reduce their dependence upon hunting, fishing, and trapping as their primary means of support. Indeed, fearing greatly that signing the Treaty would lead to their immediate confinement to reserves, the Indians had to be reassured explicitly by the

Secretary, Department of Indian Affairs (5 December 1900), Ottawa, NAC (RG 10, vol. 3564, file 82 , pt. 21).

The matter was never tested in practice as the Department of Indian Affairs began to discourage actively any exercise of the severalty option soon after the treaty had been signed (see Indian Association of Alberta, Statement on the Indian Title to Lands Surveyed "in Severalty" Under Treaty No. 8 (1980) [unpublished]).

In testimony before the Indian Claims Commission in the Fort McKay Treaty Land Entitlement Inquiry, Rem Westland, then Director General of the Specific Claims Branch, stated: "one thing that impressed itself on me as I became familiar with treaty land entitlement is that treaty land entitlement is a collective right. It is not an individual right...I was struck by the illogical points that individuals who did not have this right could reopen or constitute a collective right"("Fort McKay First Nation Treaty Land Entitlement Inquiry"(1996) 5 I.C.C.P. 13 at 48). 
Commissioners that the Treaty merely provided the opportunity to select reserves and/or lands in severalty "when you please" so as to "secure ... in perpetuity a fair portion of the land ceded, in the event of settlement advancing." 94

\section{Policy Change Required}

To the extent that the ADOFS calculation is predicated on the assumed collective nature of the right and/or on the assumed common intention of the parties, it is clear that neither assumption can support its application to the determination of outstanding land entitlement under Treaty 8. Any support the latter assumption may draw from the Lac La Ronge decision would thus appear to be of little use for purposes of justifying the applicability of current policy to this particular treaty.

In the result, it is apparent that current federal policy on TLE serves to reduce unilaterally and arbitrarily the obligations assumed by Canada pursuant to the land entitlement provisions of Treaty 8 . This discrepancy between current policy and actual obligation should be reduced by moves to amend the policy so as to bridge the existing gap between the ADOFS calculation and the current population formula called for under Treaty 8 . In the alternative, entitlement should be fixed at date of first survey only for those individuals and families actually counted at that time. It cannot be fixed for those individuals and families (whether on the DOFS paylist, arrears, absentees, late adherents, or landless transfers) not counted at that time. Until they are finally counted, in terms of being presented with the opportunity to select between contributing to reserves in common or taking lands in severalty, any natural increase on their part is a legitimate increase to their individual land entitlement (if taken in severalty) or to the land entitlement of the band on which annuity paylist they may be listed (if taken in common). In the further alternative, there remain principled reasons to broaden various elements in the ADOFS calculation. The remaining parts of this article identify three deficiencies in present policy that call for policy reform: issues related to the onus of proof, the indiscriminate inclusion of poor quality land in the land entitlement calculation, and the exclusion of individuals with paternal ancestors who received scrip.

\section{B. ONUS OF ProOF}

\section{Current Federal Policy}

Current TLE policy places the onus of proof entirely on First Nations to establish a shortfall at date of first survey. It is the sole responsibility of the First Nation to substantiate the existence of any individuals that it seeks to include in its TLE calculation, particularly

${ }^{94}$ See opening statement of Treaty 8 Commissioner David Laird, as recounted in Mair, supra note 7 at 57:

Then, as the white men are coming in and settling in the country, and as the Queen wishes the Indians to have lands of their own, we will give one square mile, or 640 acres, to each family of five; but there will be no compulsion to force Indians to go into a reserve. He who does not wish to go into a band can get 160 acres of land for himself, and the same for each member of his family. These reserves are holdings you can select when you please, subject to the approval of the Government, for you might select lands which interfere with the rights or lands of settlers. The Government must be sure that the land which you select is in the right place.

See also Commissioners Report, supra note 59 for the full quote. 
with respect to the determination of band membership at date of first survey. Only those band members who can be shown conclusively to have been alive at DOFS are entitled to be counted. Where there is no direct evidence from paylist entries, Canada has at times been willing to consider individuals of undoubted association with the band who can be shown to have been alive at DOFS, yet were not counted for TLE purposes. In such cases, Canada has required proof of birth and death or similar conclusive evidence that the individual in question was alive in the year lands were initially surveyed.

In many cases, however, bands can produce birth and/or baptismal certificates but no death certificates or other evidence for individuals who were likely to have been legitimate community members at date of first survey. Bands in such cases are made to bear the entire burden arising from the paucity of historical information that, it may be stated, was the responsibility of Canada to collect and maintain, even where it is clear that Canada has failed to perform its treaty obligations. In doing so, Canada, in principle and in effect, has unjustifiably shifted the burden of its legal and historical failures to the band.

\section{PREsumptions AND REVERSE ONUSES}

The "jealousy" with which courts protect the beneficiary of a fiduciary relationship is reflected in the flexibility with which they approach evidentiary and procedural issues. The law of fiduciaries "has all sorts of different presumptions, of varying strength and application, a whole host of rules to shift the burden or onus of proof, and almost as many different levels of rebuttal as there are fiduciary cases." ${ }^{95}$

Some presumptions are long-established in the jurisprudence. For example, courts will presume undue influence in any transaction between the parties to a fiduciary relationship that results in a manifest disadvantage to the beneficiary, ${ }^{96}$ even where the fiduciary does not personally benefit from the transaction. ${ }^{97}$ Another example arises in the context of selfdealing. There is a strong presumption that a fiduciary acting as both the vendor and purchaser of trust property (and thus exercising total control over the transaction) has exploited his or her position as a fiduciary.$^{98}$ Courts may also require proof of disclosure of all material information in any transactions between the fiduciary and beneficiary. Absent such proof, some courts have held the fiduciary liable in breach, regardless of any other facts proved. ${ }^{99}$

Ultimately, the rules of proof governing actions in breach of fiduciary duty are profoundly fact-specific, varying with the circumstances of the relationship, the nature of the alleged breach, and the inherent difficulties faced by the beneficiary in demonstrating a breach of duty. ${ }^{100}$ As such, they elude bold generalizations.

J.C. Shepherd, The Law of Fiduciaries (Toronto: Carswell, 1981) at 127.

Zamet v. Hyman, [1961] 3 All E.R. 933 (C.A.); Erlanger v. New Sombrero Phosphates Ltd., [1877-78]

3 A.C. 1218 (H.L.); and Allcard v. Skinner, [1886-1890] All E.R. 90 (C.A.).

Goodman Estate v. Geffen (1989), 98 A.R. 321, 68 Alta. L.R. (2d) 289 (C.A.).

Shepherd, supra note 95 at 157.

Brickenden v. London Loan \& Savings Co., [1934] 3 D.L.R. 465, 2 W.W.R. 545 (P.C.) at 469; Shepherd, ibid. at 129.

Shepherd, ibid. at 127 and 130 . 
As a guiding principle, however, it might be stated that "fiduciary doctrine presumes the existence of the fiduciary's breach of duty upon its allegation by a cestui que trust [beneficiary]." ${ }^{\prime 01}$ In other words:

Beneficiaries need only demonstrate, prima facie, the existence of a fiduciary relationship between the parties. The prima facie inference of breach is made by juxtaposing the beneficiary's allegation of its occurrence against the nature of the intercourse between the parties. Once a court accepts that a relationship is fiduciary and that a breach may have occurred, the burden of proof shifts to the fiduciary to disprove the existence of a breach. $^{102}$

The fiduciary may only discharge this reversed onus by demonstrating that he or she did not act in any manner other than in the best interests of the beneficiary.

Treaty 8 First Nations in many cases have strong grounds to argue both the existence of a fiduciary duty by the Crown and a subsequent breach concerning implementation of the land entitlement provisions of the treaty. ${ }^{103}$ The Crown, as fiduciary, owed the First Nations a duty of loyalty and care in discharging its obligations. This demanded, among other responsibilities, that the Crown at minimum perform its obligations under the land entitlement provisions of Treaty 8 fully and in good faith, without compromising the interests of the First Nations during the process of selection and survey. ${ }^{104}$ Implicit in this position is the responsibility of the Crown to take all reasonable measures necessary to determine the actual number of individuals entitled to be counted for land entitlement. Where it can be demonstrated that these measures were inadequate, in particular where it can be shown that individuals who should have been counted were not, a prima facie breach can be said to exist.

In many cases, therefore, Treaty 8 First Nations can satisfy the threshold for reversing the onus of proof: they can demonstrate a prima facie fiduciary relationship and they can demonstrate a prima facie breach of duty by demonstrating a failure by the Crown to count individuals who should have been counted for purposes of land entitlement. In these cases, the burden should shift to the Crown to disprove outstanding entitlement with respect to other individuals possessing reasonable historical evidence as to their association with the relevant community at date of first survey. This would include demonstrating reasonable grounds for

L. Rotman, Parallel Paths: Fiduciary Doctrine and the Crown-Native Relationship in Canada (Toronto: University of Toronto Press, 1996) at 183.

Ibid.

10. Guerin v. the Queen, [1984] 2 S.C.R. 335, [1985] I C.N.L.R. 120 [Guerin cited to S.C.R.]; R. v. Sparrow, [1990] 1 S.C.R. 1075, (1990), 4 W.W.R. 410. See also Bell \& Buss, supra note 16 at 698 : Up until 1985, the Crown ultimately controlled band membership, and the bands were subject to the Crown's decisions regarding who was eligible to adhere to treaty and who was a band member and entitled to live on the band's reserve. Thus, in addition to the general fiduciary obligation of the Crown to Indian Bands, a specific duty arises in these circumstances. The Crown's duty to act in a band's best interest and to fulfill treaty promises cannot be reconciled with the denial of land for some band members because the Crown now believes it was mistaken in according them treaty rights and band status. The band's obligations to these people and their right to share in band property arises from the Crown's conduct, mistaken or not. The consequence of the Crown's TLE policy is that the fiduciary avoids some of the costs of its own error, but visits them on the beneficiary. 
concluding that individuals excluded from any current ADOFS calculation were indeed deceased, members of other bands, or otherwise ineligible, and not simply missed and then forgotten as a result of the Crown's own negligence in conducting the initial survey. ${ }^{105}$ Considerations of this kind are of particular applicability with respect to Treaty 8 , where the fluid nature of the First Nations and their memberships, in contrast to the more stable and settled bands in the south, was well-recognized by the Crown and its officials.

To reverse the onus of proof in this way accords with the underlying rationale for relaxing the burden of proof for aggrieved beneficiaries. Beneficiaries, due to their position of vulnerability and the imbalance of power, face inherent difficulties in proving breaches of fiduciary duty. The fiduciary generally possesses greater access to material information, and a consequently greater opportunity to exploit this advantage. In the case of First Nations, uncertainty and lack of relevant information around the status of excluded band and community members arises largely because of a failure by the Crown to satisfy its duty of care in assessing properly the population of each band or community at first survey. This point assumes particular relevance as the Crown has adopted the position that it is required to take only one count, at which time the TLE of the band is fixed irrevocably. Allowing the Crown to benefit from this uncertainty and lack of current information offends the very nature of the fiduciary relationship. Given the strictness and jealousy with which the law guards the interests of beneficiaries, it seems clear that the Crown should bear the burden of disproving the eligibility of individuals with reasonable claims to entitlement where existing evidence is now unavailable to decide the matter conclusively. ${ }^{106}$

\section{POLICY CHANGE REQUIRED}

On the basis of established legal principles concerning the interpretation of treaties and the fiduciary duties of the Crown, it is submitted that the onus of proof must shift to Canada where First Nations can show (by birth certificate or baptismal record) that an individual with clear association to that band or community had been born within some reasonable period prior to date of first survey. It is suggested that this period be 30 years.

Should First Nations prove the birth of an individual within 30 years prior to date of first survey, Canada should be required to prove either death or transfer to another band prior to DOFS if it desires to exclude such an individual from an ADOFS calculation. Furthermore,

I05 The likelihood that eligible individuals will be excluded under certain not unlikely circumstances is assured in principle given the requirement under current federal policy that the burden of proof placed on First Nations be met for particular individuals taken in isolation. While it may be reasonable to exclude any particular individual born one year prior to DOFS without any further evidence that he or she was alive and a member of the band or community at DOFS, it would, on a simple statistical balance of probabilities, be entirely unreasonable to exclude more than three such individuals. Under current federal policy, however, any number of such individuals would be excluded in the absence of conclusive evidence confirming that they were alive at DOFS.

I11. Further support for this proposition is found in the approach adopted by courts in quantifying damages for breach of fiduciary duty. Fiduciary relief is founded on similar principles to trust law, rather than contract or tort, and is restitutionary in nature (see generally Guerin, supra note 103). The courts' power of relief in equity is substantial. In Guerin, the court refused to limit the band's compensation for a detrimental leasing agreement to the value of the lease that the band admitted it would have entered into. Instead, it was "presumed that the Band would have wished to develop its land in the most advantageous way possible" (supra note 103 at 362). 
should First Nations validate a TLE claim on current criteria, individuals who can be shown to have been born within 30 years of DOFS should be counted towards any determination of outstanding obligation, unless Canada can similarly prove death or transfer prior to DOFS.

\section{Quality of Land Surveyed for Treaty Land Entitlement Purposes}

\section{Current Federal Policy}

Current TLE policy and the date of first survey formula assume that all lands surveyed are to be counted equally with respect to the ADOFS calculation of the band. There is, in this sense, no distinction made between the quantity of lands surveyed and their quality, no distinction as to their suitability or unsuitability for settlement and/or economic development of the band. Each acre surveyed is equivalent to every other acre surveyed; an acre of prime farmland is equivalent to an acre of swampland or muskeg. This assumption may be challenged, however, by the provisions of Treaty 8 and the historical facts associated with the survey of entitlement lands within this treaty and the Numbered Treaties in general.

\section{HISTORICAL SURVEYS OF LANDS FOR TLE}

\section{According to Theresa Ferguson:}

In previous treaties [to Treaty 8], government perceptions of reserves were strongly linked to the practice of agriculture. By implication, a reserve should contain the lands necessary for agriculture and settlement, i.e. arable lands, hay meadows and woodlots. Surveyors were encouraged to assess and report on the value of the land for agricultural pursuits and in the pre-1899 period, in the Treaty Six area, for instance, land exchanges were made to rectify situations where land of poor quality had been surveyed for the bands. ${ }^{107}$

The relationship between reserve lands and agriculture was to persist into Treaty 8 . As noted previously, it was intended clearly that the selection and survey of reserves and/or lands in severalty would be made, if made at all, on the advance of white settlement and the subsequent decision by the bands to reduce their dependence on hunting, fishing and trapping as their primary means of support. The economic benefits provisions of the Treaty, in particular, reflect this fact. ${ }^{108}$ These provisions were drafted to reflect the apparent geographical variety and differing potential for economic development within the Treaty 8 territory. The point is stressed in the Commissioners Report:

When we conferred, after the fïrst meeting with the Indians at Lesser Slave Lake, we came to the conclusion that it would be best to make one treaty covering the whole of the territory ceded, and to take adhesions thereto from the Indians to be met at the other points rather than to make several separate treaties. The treaty was therefore so drawn as to provide three ways in which assistance is to be given to the Indians, in order to accord with the conditions of the country and to meet the requirements of the Indians in the different parts of the territory. 
In addition to the annuity, which we found it necessary to fix at the figures of Treaty Six, which covers adjacent territory, the treaty stipulates that assistance in the form of seed and implements and cattle will be given to those of the Indians who may take to farming, in the way of cattle and mowers to those who may devote themselves to cattle-raising, and that ammunition and twine will be given to those who continue to fish and hunt. The assistance in farming and ranching is only to be given when the Indians actually take to these pursuits, and it is not likely that for many years there will be a call for any considerable expenditure under these heads. The only Indians of the territory ceded who are likely to take to cattle-raising are those about Lesser Slave Lake and along the Peace River, where there is quite an extent of ranching country; and although there are stretches of cultivable land in those parts of the country, it is not probable that the Indians will, while present conditions obtain, engage in farming further than the raising of roots in a small way, as is now done to some extent. In the main the demand will be for ammunition and twine, as the great majority of the Indians will continue to hunt and fish for a livelihood. It does not appear likely that the conditions of the country on either side of the Athabasca and Slave Rivers or about Athabasca lake will be so changed as to affect hunting or trapping, and it is safe to say that so long as the fur-bearing animals remain, the great bulk of the Indians will continue to hunt and to trap. ${ }^{109}$

Three different vocations are provided for: hunting, fishing and trapping, agriculture, and cattle-raising. Those who elected to "take a reserve and cultivate the soil" would be provided with various agricultural instruments, machinery and livestock; those who preferred "to raise stock instead of cultivating the soil" would be provided with livestock and machinery; and those who continued to live in the traditional manner would receive an annual provision of ammunition and twine. The suitability of reserves and/or lands in severalty for purposes of agriculture or stock-raising would thus appear to be implied strongly from the provisions of the treaty text alone.

Furthermore, the distinction between Indian Reserve lands suitable to be counted towards the treaty land entitlement of a band and those surveyed and set aside, but not counted, was drawn with respect to the initial survey of reserve lands in Treaty 8 . In a letter dated 19 March 1902, A.W. Ponton, D.L.S., reported on his survey of Sucker Creek Indian Reserve No. $150 \mathrm{~A}$ the previous summer:

The total number of Indians in the above list is Seventy, which would entitle them to fourteen Square Miles.

The Reserve as surveyed contains 17.35 Square Miles, the apparent excess of 3.35 Square Miles is owing to swamp lands included within the Reserve, but not estimated in the area to which the Band is entitled. ${ }^{110}$

The following notation occurs on the survey plan for the reserve: "The hay and willow swamp along the Lake shore has been included in the Reserve, but three thousand acres has been deducted from the total area on account of water and waste land." "II

A similar reduction in the area of lands counted for purposes of treaty land entitlement was made with respect to Driftpile Indian Reserve No. 150, also surveyed by Ponton in 1901. As

Commissioners Report, supra note 59. The views of the 1899 Commissioners were repeated by Commissioner Macrae in his report on the 1900 Treaty 8 adhesions (see ibid.). 
stated on the plan of survey: "The hay and willow swamps along the Lake shore is included in the Reserve but has not been estimated in the area." "12 Theresa Ferguson notes:

The Sucker Creek and Driftpile cases are not unique in the inclusion of non-entitlement land in a reserve. Prior to 1901 Ponton had worked extensively in Manitoba and Saskatchewan. The principle of not counting as entitlement land swamps within the reserves was established at least since 1888. in that year Ponton reports on the summer's work in Manitoba that "in accordance with instructions received from the department, a fair allowance was enclosed to make up the deficiency caused by lakes and marshes." 113

The quality of lands to be surveyed was also considered at Swan River in 1902. The following is taken from a memorandum by Ponton to the Secretary, Department of Indian Affairs, dated 12 March 1902:

\begin{abstract}
My hope that the Indians for whom reserves have still to be surveyed will decide to take land together at Swan River is based on conversations I had with Chief Kinoosayo and Councillor Moostoos, both of whom stated they would use their influence to persuade them to do so, as the land is far more suitable at that point for farming and stock than at the points where the Indians now reside. I am also of the opinion that there is not a sufticient are of good land at these points, to allow of Indians being allotted the full area to which they are entitled. $^{114}$
\end{abstract}

Concerns as to the overall quality of lands surveyed for TLE purposes were, however, to be abandoned when Indian reserves came to be viewed increasingly by the wider population as impediments to settlement and economic development. The survey of reserve lands in later years was to occur primarily in areas where future settlement and/or economic development were perceived to be unlikely. The quality of land, as arguably measured against the intent and requirements of the Treaty, declined correspondingly.

\title{
3. POLICY CHANGE REQUIRED
}

Given the purpose for which reserve lands and/or lands in severalty were to be selected by the Indians and given the historical record and past practice of Canada, the area of lands already surveyed and set apart for the band that are unsuitable as treaty entitlement lands, by reason of their poor quality and/or unsuitability for economic development, should be deducted from the ADOFS calculation.

\section{Exclusion OF Individuals With Paternal ANCESTORS WHO RECEIVED LAND OR SCRIP}

1. CurRent FEDERAL POLICY

As noted above, the Validation Criteria and Research Guidelines state:

a) The following people are excluded from the TLE calculation to prevent "double counts":

112 DIAND, Reserve Lands Registry, Micro Plan 365, Survey of Driftpile Indian Reserve No. 150, A.W. Ponton, D.L.S., 1901.

113 Ferguson, supra note 107 at 200.

114 Ottawa, NAC (RG 10, vol. 3960, file 141977-7). 
1) anyone who has already been included in the calculation of another band's TLE or alternatively has a paternal ancestor who has already been included in the calculation of a band's TLE;

2) and anyone who has taken scrip or severalty or who has a paternal ancestor who took scrip or severalty, before they were born or of the age of majority. However, anyone who took scrip after the DOFS, is not removed from the DOFS paylist count. ${ }^{115}$

These exclusions stand in opposition to Canada's historic policy with respect to the issue of Metis scrip, wherein the prior issue of scrip to either parent alone would not disqualify children of those parents.

\section{HISTORICAL CONTEXT OF SCRIP}

Dominion Order-in-Council 1459, dated 20 July 1906 (granting authority to negotiate Treaty 10), stated:

The extinguishment of the claim of one parent shall not be held to debar from scrip any Half-breed who is resident of the said territory at the time of the making of the treaty.

Dominion Order-in-Council 1060, dated 29 May 1909 (granting authority to take adhesion to Treaty 5), stated:

The right of a Half-breed to scrip shall be considered to have been extinguished if scrip has been issued to him or to his parents or guardian for him in settlement of such right, and the issue of scrip to any Half-breed shall be deemed to have extinguished the right of the child of such Half-breed if the child was born after the date which fixed the right of the parents, but if the right of one parent has not been extinguished the fact that the right of the other has been shall not affect the right to scrip of the child of such parents.

Dominion Order-in-Council 1172, dated 12 April 1921 (granting authority to negotiate Treaty 11 ), stated:

The right of a Halfbreed to share in the grant to the Halfbreeds resident within the territory covered by the proposed treaty shall be considered to have been extinguished if such Halfbreed has at any time joined a Band of Indians under treaty, although subsequently discharged therefrom, or if scrip has been issued to him or to his parents or guardians for him in settlement of his right, and the issue of scrip to any Halfbreed shall be deemed to have extinguished the right of the child of such Halfbreed if the child was born after the date which fixed the right of the parents, but if the right of one parent has not been extinguished the fact that the right of the other has shall not affect the right of compensation of the child of such parents.

Orders-in-Council associated with Metis land grants and scrip previous to 1906 make no reference to the eligibility of a child where one parent had received scrip but the other had not (and where the one having taken scrip had not also done so on behalf of the child). The issue, it may be suspected, did not arise prior to that time. There is, therefore, no basis to conclude that a policy different from that set out in the Order-in-Council 1459 would have been adopted had the problem arisen for consideration previously. 


\section{POLICY CHANGE REQUiRED}

No justification has been put forward by Canada as to why children of paternal ancestors who received Treaty lands are at present to be excluded from further entitlement or compensation, while children of paternal ancestors who received scrip were not excluded in a similar fashion. ${ }^{116}$ It cannot be that these children would not have been considered or treated as "Indians" by the Crown at the time Treaty 8 was signed in 1899. In the $R$. $v$. Howson, ${ }^{117}$ an 1894 decision from the North-West Territories Supreme Court, the question was raised as to whether a "half-breed," his father being French and his mother Indian, was "a person of Indian blood," and thus an Indian under the Indian Act of 1886 because he belonged to an Indian band. ${ }^{118}$ It was argued that the words "any male person of Indian blood" in the Indian Act were meant to mean any person of full Indian blood or, failing that, that the blood of the father was to govern. Mr. Justice Wetmore, in delivering the judgment of the Court, rejected this argument:

It [the Indian Act] is intended to apply to a body of men who are the descendents of the aboriginal inhabitants of the country, who are banded together in tribes or bands, some of whom live on reserves and receive monies from the Government, some of whom do not. It is notorious that there are persons in those bands who are not full blooded Indians, who are possessed of Caucasian blood, in many of them the Caucasian blood very largely predominates, but whose associations, habits, modes of life, and surroundings generally are essentially Indian, and the intention of the Legislature is to bring such persons within the provisions and object of the Act, and the definition is given to the word "Indian" as aforesaid with that object. "19

He later wrote on the effect of the mother having married a white man: "Assuming she did marry as alleged ... while she herself lost her character of an Indian by such marriage, it did not affect her blood which she transmitted to her son." 120

A key principle of treaty interpretation set out by McLachlin J. in Marshall No. $l$ is that "the interpreting court must update treaty rights to provide for their modern exercise."121 Modern law as to the impermissibility of gender discrimination must certainly qualify as an acceptable basis for one such update. ${ }^{122}$

The following individuals should therefore be legitimate additional inclusions in any ADOFS calculation:

Individuals who had a father (or paternal ancestor), but not a mother (or maternal ancestor), that received land with another Band (likely to be children of late

116. For an argument that scrip recipients in general should be included in land entitlement calculations for Treaty 8 First Nations, see Bell \& Buss, supra note 16.

117 (1894), 1 Terr. L.R. 492 [Howson].

$11 \mathrm{~K} \quad \mathrm{Ibid}$. Section 2(h) of the Indian Act, supra note 61, defines "Indian" as "First. Any male person of Indian blood reputed to belong to a particular band; Secondly. Any child of such person: Thirdly. Any woman who is or was lawfully married to such person."

III) Howson, ibid. at 495.

120 Ibid. at 496.

$121 \quad$ Supra note 11 at para. 78.

122 See s. 15, Charter of Rights and Freedoms, Part 1 of the Constitution Act, 1982, being Schedule B to the Canada Act, 1982, (U.K.), 1982, c. 11. 
adherents and landless transfers). The mother (or maternal ancestor) in this case should not have received scrip or been counted for TLE.

Individuals who had a father (or paternal ancestor), but not a mother (or maternal ancestor), who took scrip or severalty - the mother (or maternal ancestor) in this case should not have received scrip or been counted for TLE.

In general, where it can be determined that one ancestor had received either land or scrip, while the other had received neither, it should not matter for TLE purposes whether the ancestor who received neither was male or female. ${ }^{123}$

\section{Proposal for Policy Change}

This article has argued that the land entitlement provisions of Treaty 8 are to be interpreted in accord with the current population formula. Entitlement is to be calculated when the obligation is met and fulfilled in its entirety. Where fulfillment extends over a period of time, the obligation is not met until the end of the process, the extent of the obligation being determined by reference to the population at the end.

Current federal policy on TLE nonetheless rejects outright any application of the current population formula, as evidenced by the restrictions present within the ADOFS calculation. The existing gap between current policy and the provisions of Treaty 8 can only be closed by a shift in that policy towards the current population formula. Only this can permit outstanding TLE claims submitted by First Nations to be assessed, negotiated and settled in proper accord with the obligations assumed by Canada under the land entitlement provisions of the Treaty.

In the alternative, it has been argued that, if land entitlement under Treaty 8 is to be fixed at date of first survey, it can be fixed only for those individuals and families actually counted at that time. It cannot be fixed for those individuals and families not counted at that time. Until they are finally counted, in terms of being presented with the opportunity to select between contributing to reserves in common or taking lands in severalty, any natural increase on their part is a legitimate increase to their individual land entitlement (if taken in severalty) or to the land entitlement of the Band on which annuity paylist they may be listed (if taken in common). The mere placement of any individual or family on a particular band list for administrative purposes does not, therefore, extinguish or alter their treaty right in this matter.

In the further alternative, it has been argued that the existing ADOFS calculation should be broadened in three ways: first, should First Nations prove the birth of an individual within 30 years prior to date of first survey, the burden of proof should shift to Canada to prove either death or transfer to another band prior to DOFS if it desires to exclude such an individual from an ADOFS calculation; second, the area of lands already surveyed and set

12.3 None of this is to imply that each case involving scrip ought not to be examined individually and in detail where possible to determine the circumstances under which it had been issued. Cases involving fraud or other improprieties should not be taken as having extinguished or diminished the treaty land entitlement rights of the individuals involved or their descendants. 
apart for the band that are unsuitable as Treaty entitlement lands, by reason of their poor quality and/or unsuitability for economic development, should be deducted from the ADOFS calculation; third, where it can be determined that one ancestor had received either land or scrip, while the other had received neither, it should not matter for TLE purposes whether the ancestor who received neither was male or female. ${ }^{124}$

In any case, and under any alternative, it has been submitted that current federal policy with respect to TLE bears little relation to the historical intentions of the parties to Treaty 8 . If the honour of the Crown is to be upheld with respect to this agreement, this policy must change.

An adjusted Date of First Survey calculation based on the arguments presented above may be summarized as follows (In this summary, "natural increase" is to be defined as the period to when the individuals and families in question are presented with the opportunity and alternative to contribute reserves in common or select lands in severalty, as required by Treaty 8 .):

ADJUSTED DATE OF FIRST SURVEY POPULATION =

Base Paylist

[Individuals and families not counted at DOFS and subject to natural increase]

$+$

[Individuals and families recorded on the relevant paylists, per current TLE policy, or individuals and families so recorded and subject to natural increase, whichever is greater]

$$
+
$$

Absentees

[Individuals and families as recorded on the relevant paylists, per current TLE policy, or individuals and families so recorded and subject to natural increase, whichever is greater]

$+$

Additional Absentees

[Individuals who can be shown conclusively to have been alive at DOFS

(as at times accepted by Canada), or individuals so recorded and subject to natural increase, whichever is greater and/or

Individuals who can be shown by the Band to have been born within 30 years of DOFS and who cannot be shown by Canada to have died or transferred to another Band prior to DOFS, or individuals so shown and subject to natural increase, whichever is greater]

$$
+
$$

Late Adherents

[Individuals and families as recorded on the relevant paylist, per current TLE policy, or individuals and families so recorded and subject to natural increase, whichever is greater]

$+$

Landless Transfers

[Individuals and families as recorded on the relevant paylist, per current TLE policy, or individuals and families so recorded and subject to natural increase, whichever is greater]

\section{Double Counts}

Scrip Recipients

[Only where both parents can be shown to have taken scrip]

The ADOFS figure so determined is to be compared to the total area of lands surveyed for the band, as adjusted downward to compensate for lands already surveyed and set apart for the Band that are unsuitable as treaty entitlement lands by reason of their poor quality. 